\title{
Piscivory in age-0 summer flounder Paralichthys dentatus with a focus on predator-induced mortality of post-settlement winter flounder Pseudopleuronectes americanus
}

\author{
David L. Taylor*, Kelly J. Cribari, Abigail Scro \\ Roger Williams University, Department of Marine Biology, One Old Ferry Road, Bristol, RI 02809, USA
}

ABSTRACT: We examined the piscivorous diet of age-0 summer flounder Paralichthys dentatus in southern New England tidal rivers, with a focus on their predatory impact on post-settlement winter flounder Pseudopleuronectes americanus. The population density, size-structure, and growth of age-0 summer flounder and winter flounder were evaluated in the Seekonk and Taunton Rivers (Rhode Island and Massachusetts, USA, respectively) between May and August/September 2009 through 2015. For a subsample of summer flounder collected during this time (20-181 mm total length, $\mathrm{TL}_{\text {; }} \mathrm{n}=743$ ), diet was assessed using direct visual analysis and PCR-based assays that detect winter flounder mitochondrial DNA within predator stomach contents. Summer flounder were generalist piscivores consuming 8 distinct fish prey taxa from both epibenthic and pelagic guilds. The most frequently observed fishes in the diet of summer flounder were age- 0 winter flounder and herring (Clupeidae) with frequencies of occurrence, $\% F$, of 2.6 and $2.0 \%$, respectively, and overall $\% F$ of fish equal to $13.6 \%$. Fish were absent in the stomachs of summer flounder $<44 \mathrm{~mm} \mathrm{TL}$, beyond which piscivory increased significantly with increasing predator size. Summer flounder 50-153 mm TL preyed on winter flounder ranging from $19-54 \mathrm{~mm} \mathrm{TL}$, resulting in predator-to-prey size ratios of 2.2-3.6 (mean $\pm \mathrm{SD}=$ $2.8 \pm 0.3$ ). Incidences of summer flounder predation on winter flounder were positively related to body size ratios, and this relationship was attributed to the enlarged mouth gape and improved prey capture abilities of larger predators. Summer flounder predation on fishes, including winter flounder, also demonstrated significant spatiotemporal variability, reflecting riverine and seasonal differences in flounder population size structure and dynamics in prey composition and availability. Deterministic model simulations estimated that age- 0 summer flounder account

*Corresponding author: dtaylor@rwu.edu

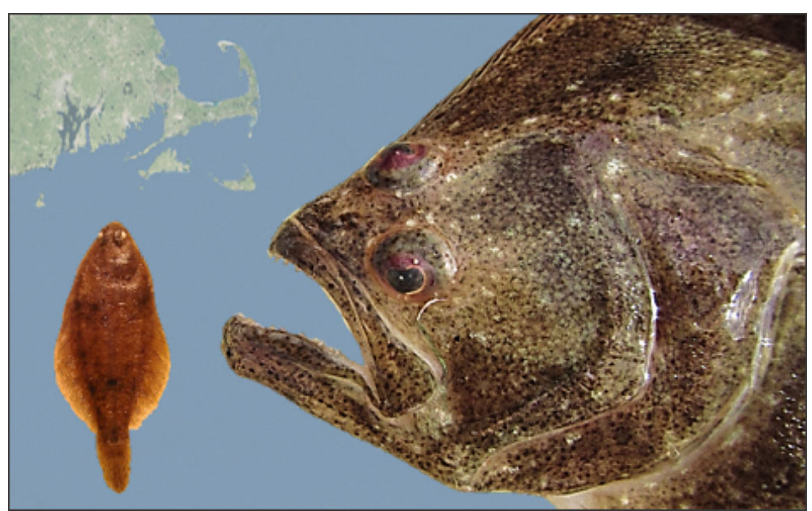

Age-0 summer flounder Paralichthys dentatus (right) are predators of winter flounder Pseudopleuronectes americanus (left) in tidal rivers that adjoin the Narragansett Bay Estuary (Rhode Island/Massachusetts, USA).

Photos: J. Reynolds and D. Taylor

for $0.7 \%$ of the daily mortality of post-settlement winter flounder (range $=0.0-2.9 \%$ ), and consumed $3.0 \%$ of the total winter flounder year-class annually (range $=0.0-12.8 \%$ ). Therefore, relative to other predatory fishes and decapod crustaceans, age-0 summer flounder likely have a nominal effect on winter flounder populations in tidal river nurseries. Summer flounder predation may be substantial, however, when multiple age-classes are considered and elevated age-0 summer flounder densities elicit a strong effect on winter flounder survival, albeit at local scales.

KEY WORDS: Paralichthys dentatus $\cdot$ Pseudopleuronectes americanus $\cdot$ Summer flounder $\cdot$ Winter flounder $\cdot$ Predation $\cdot$ Diet $\cdot$ Piscivory $\cdot$ PCR $\cdot$ Size ratio $\cdot$ Mouth gape

(C) The authors 2019. Open Access under Creative Commons by Attribution Licence. Use, distribution and reproduction are unrestricted. Authors and original publication must be credited. 


\section{INTRODUCTION}

Predation is a key source of mortality for early life history stages of marine fish (Bailey \& Houde 1989, Chambers \& Trippel 1997); therefore, fisheries research has focused on identifying factors that affect trophic interactions between piscivores and fish prey. Numerous investigations have demonstrated that predator-induced mortality of early-stage fish is strongly influenced by the relative body sizes of interacting individuals, i.e. predator-to-prey size ratios (Paradis et al. 1996, Claessen et al. 2002, and references therein). Successful foraging attempts by piscivorous predators, for example, are positively correlated with their body size due to concomitant increases in pursuit swimming ability and visual acuity (Ellis \& Gibson 1997, Wootton 1998). Similarly, the responsiveness of fish prey to predatory attacks is size-dependent, such that reaction distance and swimming performance is enhanced with increasing size (Wootton 1998). Large-bodied fish prey may also be inaccessible to certain predators because of morphological constraints, e.g. prey size exceeds the mouth gape of the predator (Manderson et al. 2000, Nilsson \& Brönmark 2000, Scharf et al. 2000). Accordingly, trophic interactions are dynamic throughout fish ontogeny and presumably respond to spatiotemporal variations in processes that affect predator-to-prey size ratios, e.g. interspecific developmental and growth rates (Taylor 2003, 2005a).

The progressive development of early-stage fish may result in age- and size-specific habitat requirements, consequently exposing individuals to novel predator types (Werner et al. 1983, Werner 1986). Flatfish, specifically, undergo a pronounced morphobehavioral metamorphosis characterized by pelagic larvae transitioning into benthic juveniles (Able \& Fahay 2010). This ontogenetic habitat shift changes predator species composition; for example, larval flatfish are vulnerable to pelagic coelenterates and zooplanktivorous fishes (Bailey \& Batty 1984, Purcell 1985, Van der Veer 1986), whereas juvenile flatfish are consumed by decapod crustaceans, demersal fishes, and avian piscivores (Leopold et al. 1998, Manderson et al. 1999, 2000, Taylor 2005a,b, Collier et al. 2014). The transition in habitat usage following metamorphosis, and altered trophic interactions, may be critical in determining year-class strength and recruitment success of flatfish (Bailey 1994, Gibson 1994).

The winter flounder Pseudopleuronectes americanus is a pleuronectid flatfish occurring in northwest and mid-Atlantic waters from Nova Scotia, Canada, southward to Maryland, USA (Pereira et al.
1999). Coastal populations of winter flounder spawn demersal eggs inside estuaries during the winter and early spring (Pearcy 1962). After hatching 14 to $21 \mathrm{~d}$ post-spawning, larval winter flounder are pelagic for 60 d (Chambers \& Leggett 1987), after which they transition to benthic juveniles during the late spring and early summer (Pearcy 1962). A variety of decapod crustaceans and demersal fishes feed on recently settled winter flounder (Manderson et al. 1999, 2000, Taylor 2005a,b, Collier et al. 2014), which is attributed to their small size at settlement $(\sim 8 \mathrm{~mm}$ total length; Able \& Fahay 2010) and weak swimming and burying capabilities (Manderson et al. 1999, Phelan et al. 2001). The result is intense predator-induced mortality, and thus possible year-class determination during the early juvenile stage (Taylor 2005a,b).

The summer flounder Paralichthys dentatus is a paralichthid flatfish whose geographic distribution and habitat requirements vary considerably across life history stages. Adult summer flounder inhabit estuarine and inner continental shelf waters in the Southern New England-Middle Atlantic Bight from Massachusetts to North Carolina, USA (Packer et al. 1999). Summer flounder spawn offshore on the continental shelf during the fall and early winter, producing pelagic eggs that hatch $\sim 3 \mathrm{~d}$ post-spawning (Packer et al. 1999). Planktonic summer flounder larvae recruit to inshore nurseries from October to May, after which they metamorphose into benthic juveniles. The geographic range of juvenile summer flounder, historically delineated as inshore nurseries between New Jersey and North Carolina, USA (Able \& Kaiser 1994), has recently extended further poleward into southern New England estuaries and coastal habitats (Taylor et al. 2016). The range extension of juvenile summer flounder is caused by elevated water temperatures in the northwest Atlantic (Smith et al. 2010, Taylor et al. 2016, Morley et al. 2018) and their associated effects on the latitudinal distribution of the adult summer flounder spawning stock (Nye et al. 2009) and over-wintering survival of early-stage flounder spawned the previous fall (Malloy \& Targett 1991).

The occurrence of juvenile summer flounder in southern New England habitats may have important consequences to resident, post-settlement winter flounder. Most notably, the spatiotemporal overlap of flounder species could promote predator-prey interactions. Taylor \& Gervasi (2017) examined the feeding habits of juvenile (age-0) summer flounder from the Seekonk and Taunton Rivers (Rhode Island and Massachusetts, respectively), 2 tidal rivers that adjoin the Narragansett Bay Estuary and serve as function- 
ally important nurseries (Taylor et al. 2016). Direct visual analysis of summer flounder stomach contents revealed ontogenetic dietary shifts toward piscine prey. Of the identifiable fish remains, winter flounder had the greatest contribution to summer flounder diet, thus verifying the existence of this predatorprey interaction in southern New England nurseries. This paper is an extension of Taylor \& Gervasi (2017) and provides a more comprehensive analysis of piscivory in age- 0 summer flounder, with a focus on their predatory impact on post-settlement winter flounder. For the latter, the objectives were 3-fold: (1) quantify the incidence of summer flounder predation on winter flounder, as revealed by conventional stomach content analysis and novel molecular genetic techniques; (2) ascertain the effect of spatiotemporally explicit abiotic and biotic factors on the predator-prey interaction; and (3) calculate the daily instantaneous and cumulative mortality rates of winter flounder, as caused by summer flounder predation, using a size-dependent deterministic model.

\section{MATERIALS AND METHODS}

\subsection{Field sampling}

A complete description of the field sampling methodology is provided by Taylor et al. (2016) and Taylor \& Gervasi (2017). Briefly, age-0 summer flounder and winter flounder were collected from the Seekonk and Taunton Rivers from May through August/September each year from 2009 through 2015 (Fig. 1). Fort- nightly sampling occurred at 3 to 4 sites per river using a beach-seine set $(15 \times 1.8 \mathrm{~m} ; 0.64 \mathrm{~cm}$ mesh size and $0.48 \mathrm{~cm}$ bunt). One seine haul was performed at each site per sampling date during daylight ( 08:00-16:00 $\mathrm{h}$ ) and $\pm 2 \mathrm{~h}$ of low tide. The area swept at each site varied due to tidal stage and beach profiles (average and range of area sampled per site: $857 \mathrm{~m}^{2}$ and 185-1848 $\mathrm{m}^{2}$ ). For each sampling effort, captured summer flounder and winter flounder were enumerated (no. ind. $\mathrm{m}^{-2}$ ) and measured for 'fresh' total length $\left(\mathrm{TL}_{\mathrm{f}} \pm 1 \mathrm{~mm}\right)$. A random subsample of flounder was immediately preserved in $70 \%$ ethanol or placed on ice and frozen at $-20^{\circ} \mathrm{C}$ in the laboratory, thereby preserving individuals for subsequent diet analysis and morphological measurements. Flounder not retained for laboratory analyses were returned to their place of capture.

Water temperature $\left({ }^{\circ} \mathrm{C}\right)$, salinity (ppt), and dissolved oxygen $\left(\mathrm{mg} \mathrm{l}^{-1}\right)$ were measured at each site per date by using a handheld YSI Model 85 meter, and these results were previously reported in Taylor \& Gervasi (2017). Briefly, mean monthly water temperature and dissolved oxygen were comparable across river sites but varied temporally, ranging from $17.6-28.4^{\circ} \mathrm{C}$ (maximal in July) and $4.4-12.3 \mathrm{mg} 1^{-1}$ (decreased monthly), respectively. Salinity gradually increased over time and differed markedly among river sites, with the upper reaches of the rivers characterized as oligohaline waters (mean salinity $\leq 5 \mathrm{ppt}$; sites SR1 and TR1) and the mid- and lower portions defined as mesohaline (salinity 6-18 ppt; sites SR2SR4 and TR2-TR3) and polyhaline (salinity $\geq 19 \mathrm{ppt}_{\text {; }}$ TR4) (Fig. 1).

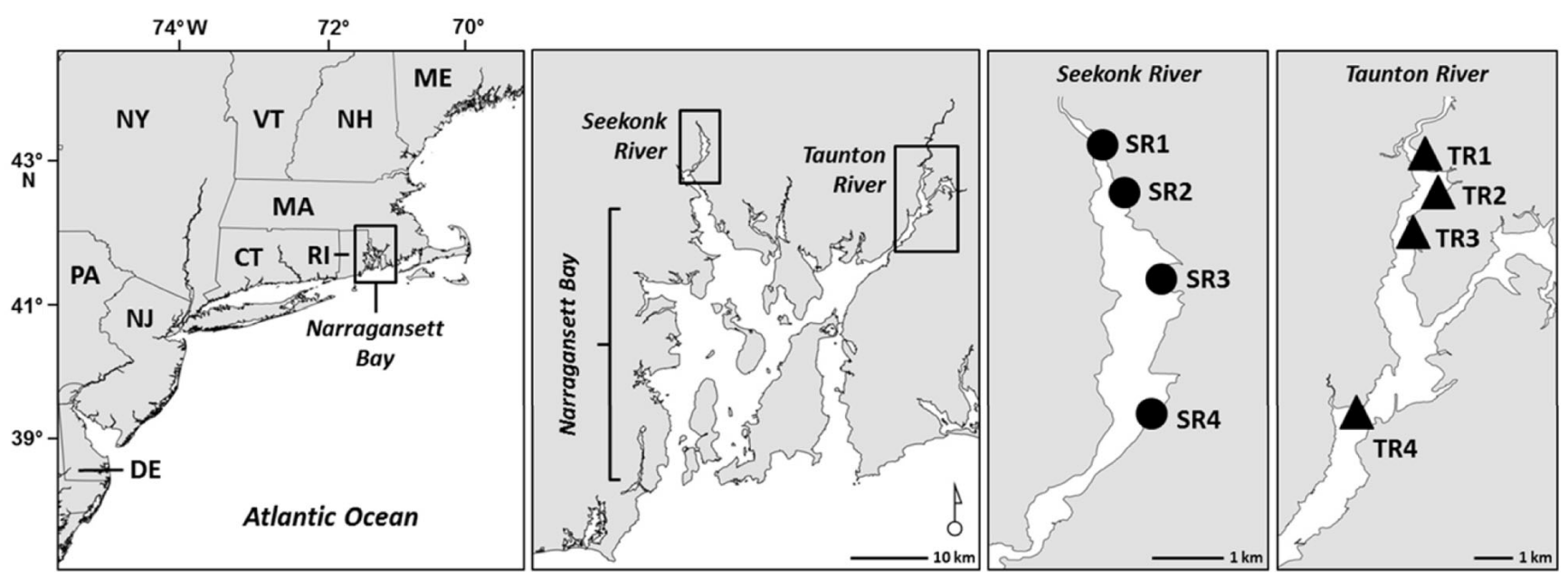

Fig. 1. Seekonk River (SR), Rhode Island, and Taunton River (TR), Massachusetts, (USA) with points denoting collection sites of age-0 summer flounder Paralichthys dentatus and winter flounder Pseudopleuronectes americanus. Four sites were sampled fortnightly in each river (SR1-SR4; TR1-TR4) from May to August/September 2009-2015, with the exception of SR3 and TR3, which were surveyed 2009-2011 


\subsection{Flounder size structure, population density, and growth rates}

For each year (2009 through 2015) and river (Seekonk and Taunton), summer flounder and winter flounder length-frequency distributions were created by compiling monthly catch data (May through August/September) and organizing body sizes into intervals of $5 \mathrm{~mm} \mathrm{TL}$. As described by Taylor et al. (2016), intraspecific cohorts were identified by visually inspecting the length-frequency distributions, and then verified using the modal progression routine of FiSAT II (Gayanilo et al. 2002).

Summer flounder and winter flounder population densities analyzed separately by river and year were determined at daily increments by fitting a normal density function to catch data over time:

$$
\rho_{t}=\left[\frac{1}{\sigma \sqrt{2 \pi}} \mathrm{e}^{-0.5[(t-\mu) / \sigma]^{2}}\right] \cdot \varepsilon
$$

where $\rho_{t}$ is the density of summer flounder or winter flounder per seine haul (no. ind. $\mathrm{m}^{-2}$ ) at time $t$ (day of year, DOY), $\mu$ is the arithmetic mean of the distribution that indicates the DOY of maximum density, $\sigma$ is the standard deviation of the distribution, and $\varepsilon$ is a correction parameter that converts the probability mass function to units of density. The dates of maximum flounder density $(\mu)$ were determined by backcalculating intraspecific growth models (Eq. 2; see below) to the DOY on which summer flounder mean body sizes were $13 \mathrm{~mm} \mathrm{TL}_{\mathrm{f}}$ and winter flounder were $8 \mathrm{~mm} \mathrm{TL}$ (i.e. size at settlement; Able \& Fahay 2010). The remaining parameters of the normal density function $(\sigma$ and $\varepsilon$ ) were determined by non-linear least-squares analysis. Finally, pairwise KolmogorovSmirnov (K-S) tests were performed on summer flounder and winter flounder catch data, pooled across years, to compare intraspecific density distributions from the Seekonk and Taunton Rivers against the null hypothesis that samples were from populations with the same parametric distribution (Sokal \& Rohlf 1981). Here and elsewhere, statistical analyses were performed using SAS ver. 9.1, and significance was set a priori at $\alpha=0.05$.

Summer flounder and winter flounder growth rates analyzed separately by river and year were determined by first fitting logarithmic regression models to body size data measured during field sampling:

$$
\mathrm{TL}_{\mathrm{f}, t}=\alpha+\beta \times \ln (t)
$$

where $\mathrm{TL}_{\mathrm{f}, t}$ is the mean 'fresh' TL of summer flounder or winter flounder per seine haul (mm) at time $t$, and $\alpha$ and $\beta$ are intercept and slope parameters estimated by least-squares analysis. Results from the regression models were used to estimate flounder growth rates during a standardized time period (21 May to 10 September; DOY $=141-253$, which represents the range of dates examined in this study):

$$
G=\frac{\mathrm{TL}_{\mathrm{f}, \text { Final }}-\mathrm{TL}_{\mathrm{f}, \text { Initial }}}{t_{\text {Final }}-t_{\text {Initial }}}
$$

where $G$ is the growth rate of summer flounder or winter flounder $\left(\mathrm{mm} \mathrm{TL}_{\mathrm{f}} \mathrm{d}^{-1}\right), \mathrm{TL}_{\mathrm{f}, \text { Final }}$ and $\mathrm{TL}_{\mathrm{f}, \text { Initial }}$ is the 'fresh' TL of flounder (mm) obtained on Day 253 $\left(t_{\text {Final }}\right)$ and Day $141\left(t_{\text {Initial }}\right)$, respectively. Lastly, analysis of covariance (ANCOVA) models were used to examine differences in summer flounder and winter flounder growth rates (and predator-to-prey size ratios; see Section 2.6) between the Seekonk and Taunton Rivers, with DOY (ln-transformed) as the covariate and river as the discrete explanatory variable. For these analyses, Eq. (2) was applied to intraspecific $\mathrm{TL}_{\mathrm{f}, t}$ data pooled across years.

\subsection{Visual analysis of summer flounder diet}

Summer flounder previously preserved in $70 \%$ ethanol were measured for 'preserved' $\mathrm{TL}\left(\mathrm{TL}_{\mathrm{p}}\right.$; $\pm 1 \mathrm{~mm}$ ) in the laboratory. Prey were then extracted from summer flounder stomachs, transferred to $3.7 \mathrm{ml}$ borosilicate vials with $70 \%$ ethanol, and later visually identified to the lowest practical taxon using stereoscopic microscopes, as reported by Taylor \& Gervasi (2017). Each fish taxon's contribution to the diet of summer flounder was expressed as frequency of occurrence $(\% F)$, which equaled the number of summer flounder stomachs containing a specific fish taxon divided by the total number of examined stomachs. When possible, fish prey recovered from summer flounder stomachs were measured for $\mathrm{TL}_{\mathrm{p}}$ using Vernier calipers $( \pm 0.01 \mathrm{~mm})$.

\subsection{Molecular genetic analysis of summer flounder diet}

The majority of fish prey recovered from summer flounder stomachs were categorized as 'unidentified fish' (Table 1; see Section 3.2). Accordingly, molecular genetic techniques were used to determine if the unidentified fish were winter flounder by testing for the presence of intraspecific genomic DNA. For each unidentified fish recovered from summer flounder stomachs $(\mathrm{n}=60), \sim 5 \mathrm{mg}$ wet weight of tissue were removed and transferred to $1.5 \mathrm{ml}$ microcentrifuge 
Table 1. Frequency of occurrence $(\% F)$ of fish prey in the stomachs of summer flounder Paralichthys denatus from 4 sites in the Seekonk River (SR1-SR4) and Taunton River (TR1-TR4) (Rhode Island and Massachusetts, USA, respectively; see Fig. 1). The numbers of stomachs analyzed from each river site (n) are reported. Winter flounder Pseudopleuronectes americanus occurrences in summer flounder stomachs were determined from visual inspection and PCR analysis confirmed via DNA sequencing. Mean preserved total lengths (ranges in parentheses, $\mathrm{mm}$ ) are also presented for intact fish prey that were recovered from summer flounder stomachs

\begin{tabular}{|lccccccccc}
\hline \multirow{2}{*}{ Fish taxon } & \multicolumn{3}{c}{ Seekonk River } & \multicolumn{3}{c}{ Taunton River } & \multirow{2}{*}{ Prey total length } \\
& SR1 & SR2 & SR3 & SR4 & TR1 & TR2 & TR3 & TR4 \\
\hline Unidentified fish & 11.8 & 3.9 & 2.5 & 5.6 & 20.0 & 4.6 & 9.6 & 0.0 \\
Winter flounder & 7.8 & 0.8 & 0.0 & 1.4 & 0.0 & 0.0 & 0.0 & 0.0 & $29.3(17.5-51.2)$ \\
Herring (Clupeidae) & 0.5 & 0.0 & 0.0 & 0.0 & 8.3 & 5.5 & 5.8 & 0.0 & $25.0(20.0-29.2)$ \\
Northern pipefish Syngnathus fuscus & 0.0 & 0.8 & 0.0 & 0.0 & 0.0 & 0.9 & 3.8 & 0.0 & $24.4(17.5-30.7)$ \\
Gobies (Gobiidae) & 0.0 & 0.0 & 0.0 & 0.0 & 1.7 & 0.0 & 0.0 & 0.0 & 38.0 \\
White sucker Catostomus commersoni & 1.5 & 0.0 & 0.0 & 0.0 & 0.0 & 0.0 & 0.0 & 0.0 & $22.0(18.8-24.0)$ \\
Atlantic silverside Menidia menidia & 0.0 & 0.0 & 0.0 & 0.7 & 0.0 & 0.9 & 0.0 & 0.0 & 27.7 \\
American eel Anguilla rostrata & 0.5 & 0.0 & 0.0 & 0.0 & 0.0 & 0.0 & 0.0 & 0.0 & 55.4 \\
Largemouth bass Micropterus salmoides & 0.5 & 0.0 & 0.0 & 0.0 & 0.0 & 0.0 & 0.0 & 0.0 & 34.0 \\
Overall \%F of fish & 21.1 & 5.5 & 2.5 & 7.7 & 26.7 & 11.9 & 19.2 & 0.0 & \\
n & 204 & 127 & 40 & 143 & 60 & 109 & 52 & 8 & \\
\hline
\end{tabular}

tubes. Tissue extraction and subsequent genetic analyses were also performed for (1) field-collected age-0 winter flounder, i.e. non-consumed winter flounder; (2) winter flounder recovered from summer flounder stomachs, i.e. consumed winter flounder ( $\mathrm{n}=$ 17); and (3) field-collected age-0 summer flounder and other potential prey, i.e. predator and prey species that were not the target of molecular assays, hereafter referred to as 'non-target' predator and prey. Non-target prey of summer flounder included fish (windowpane flounder Scophthalmus aquosus, hogchoker Trinectes maculatus, mummichog Fundulus heteroclitus, striped killifish F. majalis, threespine stickleback Gasterosteus aculeatus, fourspine stickleback Apeltes quadracus, goby Gobiosoma sp., northern pipefish Syngnathus fuscus, and American eel Anguilla rostrata), crustaceans (sand shrimp Crangon septemspinosa, Atlantic mud crab Panopeus herbstii, blue crab Callinectes sapidus, and long-clawed hermit crab Pagurus longicarpus), polychaetes (Nereis spp.), and mollusks (eastern oyster Crassostrea virginica, softshell clam Mya arenaria, and eastern mud snail Nassarius obsoleta). Genomic DNA was extracted from each $5 \mathrm{mg}$ sample using a Qiagen DNeasy Blood and Tissue Kit following a modified spin-column protocol for animal tissues. To increase DNA yield, specifically, the elution step was repeated twice with a single $100 \mu \mathrm{l}$ volume of Buffer AE. The nucleic acid concentrations and quality of DNA of all tissue types were determined by spectrophotometry (NanoDrop 2000c Spectrophotometer, Thermo Scientific).

A species-specific polymerase chain reaction (PCR)based method was used to amplify a 208 bp sequence of winter flounder DNA from prepared samples. The oligonucleotide primers implemented in this study (WF208) were first identified by Collier et al. (2014) and were synthesized by Integrated DNA Technologies (Coralville, Iowa, USA). The WF208 primer set targets the mitochondrial non-coding control region (D-loop) of the winter flounder genome (GenBank accession number U12068), with 4 sections of the D-loop used to create the forward and reverse primers (Collier et al. 2014). The PCR-based and gel electrophoresis methods described herein follow the protocol of Collier et al. (2014) with minor modifications. A $12.5 \mu \mathrm{l}$ small-scale PCR reaction was initiated by combining $10.5 \mu \mathrm{l}$ of $2 \times$ MyTaq Red DNA polymerase (Bioline USA), $0.5 \mu \mathrm{l}$ of each $10 \mu \mathrm{M}$ WF208 primer, and $1 \mu \mathrm{l}$ of template DNA. Note that when DNA concentrations of prepared samples were $<15 \mathrm{ng} \mathrm{ul}^{-1}, 2 \mu \mathrm{l}$ of template DNA were added to the reaction (total volume $=13.5 \mu \mathrm{l}$ ). The PCR reaction was performed in a Bio-Rad C1000 and DNA Engine Peltier thermal cycler under the following conditions: 2 min of initial denaturation at $95^{\circ} \mathrm{C}_{i} 35$ cycles of $30 \mathrm{~s}$ at $95^{\circ} \mathrm{C}, 30 \mathrm{~s}$ at $54^{\circ} \mathrm{C}$, and $90 \mathrm{~s}$ at $72^{\circ} \mathrm{C}_{i} 10 \mathrm{~min}$ of final extension at $72^{\circ} \mathrm{C}$; and hold at $4^{\circ} \mathrm{C}$. The reaction products, i.e. amplicons, were visualized using gel electrophoresis in $1 \%$ agarose gels with $100 \mathrm{ml}$ of a $1 \times$ Tris-Acetate-EDTA buffer and stained with $5 \mu$ of GelRed (Biotium) per $100 \mathrm{ml}$ of gel solution. PCR products were viewed using UV trans-illumination through a Kodak 1D 3.6 imager (Kodak Scientific Imaging Systems).

Finally, large-scale PCR reactions for the purposes of DNA sequencing were performed at a total vol- 
ume of $47 \mu$ using previously described concentrations. Seven subsamples across 3 tissue types were chosen for this reaction because of their successful amplification of the targeted gene sequences during the small-scale PCR, including: non-consumed winter flounder $(\mathrm{n}=2)$; consumed winter flounder, as determined by visual analysis $(\mathrm{n}=3)$; and previously unidentified fish suspected to be winter flounder, as determined by PCR methods $(n=2)$. Gel electrophoresis was used to isolate the desired products, and subsequent extraction and purification of the resulting DNA followed the Wizard SV Gel and PCR Clean-Up System protocol (Promega). Single-strand Sanger sequencing was carried out at the Rhode Island Genomics \& Sequencing Center (University of Rhode Island, Kingston, Rhode Island), and was performed using $2 \mu \mathrm{l}$ of $2.5 \mu \mathrm{M}$ of the WF208 forward primer and $2.5 \mathrm{ng}$ of DNA per 100 bases, with a final volume of $12 \mu \mathrm{l}$. Sequences were then identified to the species level by comparing against GenBank using BLAST (GenBank accession number U12068.1).

\subsection{Flounder morphological relationships}

Early-stage flounder kept in $70 \%$ ethanol or other preservatives are prone to shrinkage and decreases in body length (Tucker \& Chester 1984, Hjörleifsson \& Klein-MacPhee 1992), thus making direct comparisons to $\mathrm{TL}_{\mathrm{f}}$ problematic. In this study, to account for decreases in flounder length owing to ethanol preservation, linear least-squares regression models were used to examine the relationship between $\mathrm{TL}_{\mathrm{f}}$ and $\mathrm{TL}_{\mathrm{p}}$. The $\mathrm{TL}_{\mathrm{f}}-\mathrm{TL}_{\mathrm{p}}$ relationships were derived from the analysis of 87 summer flounder and 100 winter flounder collected from the Seekonk and Taunton Rivers. Flounder were measured for $\mathrm{TL}_{\mathrm{f}}$ immediately after capture (mean $\pm \mathrm{SD}, \mathrm{TL}_{\mathrm{f}}$ : summer flounder $=87.0 \pm 30.6 \mathrm{~mm}$ [range $=32-150 \mathrm{~mm}$ ]; winter flounder $=61.4 \pm 16.0 \mathrm{~mm}$ [range $=23-91 \mathrm{~mm}]$ ), preserved in $70 \%$ ethanol for $\geq 2 \mathrm{wk}$, and individually re-measured for $\mathrm{TL}_{\mathrm{p}}\left(\mathrm{TL}_{\mathrm{p}}\right.$ : summer flounder $=82.5 \pm$ $28.9 \mathrm{~mm}$ [range $=30-143 \mathrm{~mm}$ ]; winter flounder $=$ $58.5 \pm 15.3 \mathrm{~mm}$ [range $=22-89 \mathrm{~mm}$ ]) in the laboratory. The pairwise length data were then regressed to produce intraspecific $\mathrm{TL}_{\mathrm{f}}-\mathrm{TL}_{\mathrm{p}}$ linear models (Eqs. 4 and 5; see Section 3.4 and Table 2).

An important objective of this study was to examine summer flounder predation on winter flounder as a function of predator-prey size relationships. However, the winter flounder recovered from summer flounder stomachs were typically masticated (e.g. damaged caudal fins), thereby precluding direct measurements of their original TLs. Accordingly, the sagittal otoliths of winter flounder recovered from summer flounder stomachs were extracted and prepared using routine procedures (Secor et al. 1991), and subsequently measured for otolith maximum linear length (OL) with the aid of stereoscopic microscopes equipped with stage micrometers $( \pm 0.05 \mu \mathrm{m})$. OLs were then incorporated into a non-linear (exponential) least-squares regression model to predict the original $\mathrm{TL}_{\mathrm{p}}$ of consumed winter flounder (Eq. 6; see Section 3.4 and Table 2). The predictive $\mathrm{TL}_{\mathrm{p}}-\mathrm{OL}$ relationship was derived from the analysis of 51 winter flounder collected from the Seekonk and Taunton Rivers between May and August 2011 through 2013. Field-collected winter flounder were immediately preserved in $70 \%$ ethanol, measured for $\mathrm{TL}_{\mathrm{p}}$ and $\mathrm{OL}$ in the laboratory (mean $\pm \mathrm{SD}: \mathrm{TL}_{\mathrm{p}}=57.4 \pm 18.2 \mathrm{~mm}$ [range $=25-89 \mathrm{~mm}] ;$ OL $=1.6 \pm 0.4 \mu \mathrm{m}$ [range $=$ $0.7-2.2 \mu \mathrm{m}]$ ), and pairwise length data were regressed to produce the $\mathrm{TL}_{\mathrm{p}}-\mathrm{OL}$ exponential model. A linear least-squares regression model was then used to examine the relationship between the $\mathrm{TL}_{\mathrm{f}}$ of summer flounder visually confirmed to feed on winter flounder $\left(\mathrm{TL}_{\mathrm{f}}\right.$ converted from $\mathrm{TL}_{\mathrm{p}}$ using Eq. 4 ) and the predicted $\mathrm{TL}_{\mathrm{f}}$ of winter flounder recovered from summer flounder stomachs (Eqs. 5 and 6) (see Section 3.4 and Table 2).

Summer flounder mouth gape and winter flounder body depth were examined to evaluate the putative morphological constraints on the predator-prey interaction. In the laboratory, previously frozen flounder were thawed and measured for non-ethanol preserved TL using Vernier calipers $( \pm 0.01 \mathrm{~mm})$, hereafter also denoted as $\mathrm{TL}_{\mathrm{f}}$ (mean $\pm \mathrm{SD} \mathrm{TL}_{\mathrm{f}}$ : summer flounder $=$ $52.4 \pm 22.7 \mathrm{~mm}$ [range $=20-137 \mathrm{~mm}$ ]; winter flounder $=44.1 \pm 12.2 \mathrm{~mm}$ [range $=17-79 \mathrm{~mm}]$ ). Using the same calipers, summer flounder mouth gape $\left(\mathrm{MG}_{\mathrm{i}} \mathrm{n}=\right.$ 247) was measured as the maximum linear distance between the upper pre-maxillary and lower dentary jaw bones with the mouth stretched open (mean \pm SD $\mathrm{MG}=8.3 \pm 4.0 \mathrm{~mm}$ [range $=2.7-21.2 \mathrm{~mm}$ ]). Winter flounder body depth $\left(\mathrm{BD}_{i} \mathrm{n}=278\right)$ was measured as the maximum dorso-ventral linear distance with the dorsal and anal fins pressed against the body wall $($ mean $\pm \mathrm{SD} \mathrm{BD}=14.7 \pm 4.4 \mathrm{~mm}$ [range $=$ 5.4-27.1 mm]). Summer flounder MG and winter flounder BD were regressed with the flounders' respective $\mathrm{TL}_{\mathrm{f}}$ to produce $\mathrm{MG}-\mathrm{TL}_{\mathrm{f}}$ and $\mathrm{BD}-\mathrm{TL}_{\mathrm{f}}$ linear models (Eqs. 7 and 8; see Section 3.4 and Table 2). Linear least-squares regression analysis was then used to relate summer flounder MG to the BD of winter flounder recovered from summer flounder stomachs (Eqs. 4-8; see Section 3.4 and Table 2). 


\subsection{Factors affecting summer flounder predation on fish and winter flounder}

Multivariate logistic regression analyses, employing a stepwise selection process, were used to test for a significant relationship of 2 response variables (i.e. occurrence of 'fish' or 'winter flounder' in summer flounder stomachs) with several abiotic and biotic explanatory variables. The explanatory variables incorporated into the 'fish' regression model were specific to a field sampling effort (i.e. seine haul by date and river site) and included date of summer flounder capture (DOY), water temperature $\left({ }^{\circ} \mathrm{C}\right)$, salinity (ppt), dissolved oxygen $\left(\mathrm{mg} \mathrm{l}^{-1}\right)$, summer flounder population density (no. ind. $\mathrm{m}^{-2}$ ), and summer flounder $\mathrm{TL}_{\mathrm{f}}$ $\left(\mathrm{mm}_{i} \mathrm{TL}_{\mathrm{p}}\right.$ measured directly for summer flounder used in stomach content analysis and converted to $\mathrm{TL}_{\mathrm{f}}$ using Eq. 4). The 'winter flounder' regression model included the aforementioned explanatory variables, as well as winter flounder population density (no. ind. $\mathrm{m}^{-2}$ ), mean winter flounder $\mathrm{TL}_{\mathrm{f}}(\mathrm{mm})$, and the predator-to-prey size ratio (individual summer flounder $\mathrm{TL}_{\mathrm{f}} /$ mean winter flounder $\mathrm{TL}_{\mathrm{f}}$ ). Chisquared values were calculated to test the significance of each explanatory variable because data were treated as frequency responses (presence or absence of fish or winter flounder in summer flounder stomachs, the latter determined by visual and molecular analysis) rather than continuous responses, and, for a given explanatory variable, the significance level for entry and retention into the regression model was $p<0.05$. Finally, the natural logarithm of the ratio of response frequencies (Logits) was used to estimate parameters of each linear model. The proportion of summer flounder stomachs containing fish or winter flounder $\left(P_{t}\right)$ at time $t$ was equal to:

$\operatorname{Logit}\left(P_{t}\right)=\log \left(\frac{P_{t}}{1-P_{t}}\right)=\alpha+\beta_{1} X+\beta_{2} X+\beta_{3} X \ldots$

where $\alpha$ is the intercept parameter, $\beta_{1-3}$ are vectors of the slope parameters, and $X, Y$, and $Z$ are hypothetical explanatory variables that satisfied the entry and retention requirements for the regression analyses.

\subsection{Modeling winter flounder mortality owing to summer flounder predation}

The average and maximum daily instantaneous mortality rate $\left(Z_{\text {avg }}\right.$ and $\left.Z_{\max }\right)$ and cumulative mortality rate $(M)$ of age-0 winter flounder, as caused by summer flounder predation, were calculated using a deterministic model (Taylor 2005a,b). The model was developed to track the daily growth and survival of a single cohort of post-settlement winter flounder in the Seekonk and Taunton Rivers for each year (2009 through 2015). The start period of the model was determined by using Eq. (2) to back-calculate winter flounder growth to the DOY when the mean body size equaled $8 \mathrm{~mm} \mathrm{TL}_{\mathrm{f}}$. The total density of each winter flounder cohort was initially 8 ind. $\mathrm{m}^{-2}$, and their temporal settlement pattern was modeled as a normal distribution (Eq. 1), with $\mu=$ DOY when mean winter flounder size was $8 \mathrm{~mm} \mathrm{TL}_{\mathrm{f}}$ and $\sigma=10 \mathrm{~d}$. The peak of the normal distribution represents the maximum winter flounder density at time $t\left(\rho_{\max }\right)$ and was 0.319 ind. $\mathrm{m}^{-2}$. The total abundance and temporal distribution of winter flounder modeled for this exercise were based on historical data from several northwest Atlantic estuaries during the spring and summer (Sogard et al. 2001, Curran \& Able 2002, Yencho et al. 2015, Taylor et al. 2016).

For a given river and year, the deterministic predation mortality model was used to calculate the number of surviving winter flounder at daily time steps:

$$
\mathrm{N}_{t}=\mathrm{N}_{t-1}-\left(\rho_{\mathrm{SF}, t} \times P_{t}\right)
$$

where $\mathrm{N}_{t}$ is the number of winter flounder $\mathrm{m}^{-2}$ surviving to time $t, N_{t-1}$ is the number of winter flounder $\mathrm{m}^{-2}$ at the previous daily time step, $\rho_{\mathrm{SF}, t}$ is the density of summer flounder (no. ind. $\mathrm{m}^{-2}$ ) of a mean $\mathrm{TL}_{\mathrm{f}}$ at time $t$, and $P_{t}$ is the proportion of summer flounder stomachs containing winter flounder, as estimated from the logistic regression model (Eq. 9). Only those explanatory variables significant at $p<0.05$ were incorporated in the logistic model, and these variables were the predator-to-prey size ratio $\left(R_{t}\right)$ and salinity $\left(S_{t}\right.$ ppt) at time $t$ (see Section 3.5 ). The population density of summer flounder incorporated into Eq. (10) was re-calculated daily based on Eq. (1), whereas winter flounder density was estimated daily according to additions via benthic settlement and losses attributed to summer flounder predation. The size structures of summer flounder and winter flounder at daily increments were estimated with Eq. (2), and the results were used to calculate $R_{t}$ (i.e. mean summer flounder $\mathrm{TL}_{\mathrm{f}} /$ mean winter flounder $\mathrm{TL}_{\mathrm{f}}$ ) for inclusion in Eq. (9). For initial model simulations, $S_{t}$ was held constant at $5 \mathrm{ppt}$ and was representative of conditions in the upper reaches of the tidal rivers (Taylor \& Gervasi 2017; Fig. 1). Further, predatory summer flounder were modeled to consume 1.24 winter flounder per feeding episode (i.e. mean no. winter flounder per predator stomach; see Section 3.4) and feed twice in a $24 \mathrm{~h}$ period (Malloy \& Targett 1991, Yamamoto \& Tominaga 2007). 
Table 2. Summary statistics for univariate linear and exponential regression models used to examine morphological relationships in summer flounder (SF) and winter flounder (WF). Model variables include: SF and WF preserved and fresh total length $\left(\mathrm{TL}_{\mathrm{p}}\right.$ and $\mathrm{TL}_{\mathrm{f}}$, respectively; $\left.\mathrm{mm}\right)$; WF sagittal otolith maximum length $(\mathrm{OL}, \mu \mathrm{m}) ; \mathrm{SF}$ mouth gape $\left(\mathrm{MG}_{;} \mathrm{mm}\right)$; and $\mathrm{WF}$ body depth $(\mathrm{BD}, \mathrm{mm})$. All models are significant at $\mathrm{p}<0.0001$. Equation numbers as sequentially listed in the text are also presented

\begin{tabular}{|lcccc|}
\hline Regression model & Equation & $\mathrm{n}$ & $\mathrm{F}$ & $\mathrm{R}^{2}$ \\
\hline $\mathrm{SF}: \mathrm{TL}_{\mathrm{f}}=1.0549 \times \mathrm{TL}_{\mathrm{p}}-0.1174$ & $(4)$ & 87 & 26006 & 0.997 \\
$\mathrm{WF}: \mathrm{TL}_{\mathrm{f}}=1.0436 \times \mathrm{TL}_{\mathrm{p}}+0.3527$ & $(5)$ & 100 & 25136 & 0.996 \\
$\mathrm{WF}: \mathrm{Log}\left(\mathrm{TL}_{\mathrm{p}}\right)=0.3502 \times \mathrm{OL}+1.1704$ & $(6)$ & 51 & 578 & 0.922 \\
$\mathrm{SF}: \mathrm{MG}=0.1735 \times \mathrm{TL}_{\mathrm{f}}-0.8124$ & $(7)$ & 247 & 24948 & 0.990 \\
$\mathrm{WF}: \mathrm{BD}=0.356 \times \mathrm{TL}_{\mathrm{f}}-1.0327$ & $(8)$ & 278 & 16325 & 0.983 \\
\hline
\end{tabular}

The daily instantaneous mortality rate of winter flounder, analyzed separately by river and year, was averaged from the projected day of settlement to Day $253\left(Z_{\text {avg }}\right)$, and the maximum daily instantaneous mortality $\left(Z_{\max }\right)$ represented the largest value obtained during this time period. Annual cumulative mortality rates of winter flounder $(M)$ in each river were calculated as the total number of individuals eaten by summer flounder $\mathrm{m}^{-2}$ divided by the initial cohort size ( 8 winter flounder $\mathrm{m}^{-2}$ ). Finally, to account for natural variations in environmental conditions and flounder population dynamics, additional model simulations were performed to estimate winter flounder $M$ over a broad range of salinity (0-30 ppt), predator-to-prey size ratios (1-4), summer flounder maximum density (i.e. peak of normal density function in Eq. $1 ; 0.01-0.8$ ind. $\mathrm{m}^{-2}$ ), and winter flounder initial cohort size (4-14 ind. $\mathrm{m}^{-2}$ ). For these final simulations, flounder density and length models incorporated into Eq. (10) were generated by pooling data across rivers and years.

\section{RESULTS}

\subsection{Flounder size structure, population density, and growth rates}

Summer flounder and winter flounder early season length-frequency distributions verified the occurrence of 1 cohort per species, composed exclusively of age-0, post-settlement juveniles. In May, for example, flounder length frequencies were consistently unimodal, irrespective of year (2009 through 2015) and river (Seekonk and Taunton) (Fig. 2). The mean total length $\left(\mathrm{TL}_{\mathrm{f}}\right.$ averaged across years) of summer flounder in May was $44.5 \mathrm{~mm}$ (range = 23-82 $\mathrm{mm}$ ) and $42.8 \mathrm{~mm}$ (range $=32-55 \mathrm{~mm}$ ) in the Seekonk and Taunton Rivers, respectively. Winter flounder were similarly sized in May, with a mean $\mathrm{TL}_{\mathrm{f}}$ of $37.8 \mathrm{~mm}$ (range $=20-77 \mathrm{~mm}$ ) in the Seekonk River and $41.9 \mathrm{~mm}$ (range = 28-57 mm) in the Taunton River.

Further analysis of length-frequency distributions indicated that flounder cohorts persisted in June and July, with distributions generally shifting to larger body sizes and broadening in range across months (Fig. 2). Despite these interspecific similarities, patterns in flounder size structure differed in several fundamental respects. First, summer flounder experienced more pronounced positive shifts in their lengthfrequency distributions over time relative to winter flounder. Between May and July, for example, the mean $\mathrm{TL}_{\mathrm{f}}$ of summer flounder increased by $49.3 \mathrm{~mm}$ (averaged across years and rivers), whereas winter flounder $\mathrm{TL}_{\mathrm{f}}$ only increased by $19.4 \mathrm{~mm}$ during the same time period. Second, summer flounder occurred over a wider range of $\mathrm{TL}_{\mathrm{f}}$ in June and July in comparison to winter flounder (mean difference between maximum and minimum $\mathrm{TL}_{\mathrm{f}}=103.3$ and $65.0 \mathrm{~mm}$ for summer flounder and winter flounder, respectively), and these trends were consistent in the Seekonk and Taunton Rivers. Third, irrespective of species, flounder inhabiting the Taunton River in June and July were $\sim 8-15 \%$ larger with respect to $\mathrm{TL}_{\mathrm{f}}$ relative to conspecifics from the Seekonk River (Fig. 2).

Winter flounder unimodal length-frequency distributions persisted in August/September, yet the body size of these individuals increased modestly (mean increase in $\mathrm{TL}_{\mathrm{f}}$ between July and August/September = 5.0 and $3.3 \mathrm{~mm}$ in the Seekonk and Taunton Rivers, respectively; Fig. 2). Conversely, summer flounder mean $\mathrm{TL}_{\mathrm{f}}$ increased appreciably during this time (mean increase $=17.3$ and $28.6 \mathrm{~mm}$ in the respective rivers), but the modality of the length-frequency distributions varied by river and year. In August/September, summer flounder length-frequency distributions were unimodal in the Taunton River, irrespective of year (2009 and 2015), as well as in the Seekonk River in 2011. However, bimodal distributions were characteristic of summer flounder in the Seekonk River in 2009 and 2013, with peak distributions occurring at approximately 75 and $150 \mathrm{~mm} \mathrm{TL}_{\mathrm{f}}$ (Fig. 2).

The magnitude and timing of maximal flounder population density differed by species, river, and year (Table 3). Summer flounder density was greatest in 2009 in the Seekonk and Taunton Rivers (1.05 and 0.69 ind. $\mathrm{m}^{-2}$, respectively), and across years, densities were significantly higher in the Seekonk River relative to the Taunton River (mean $\pm \mathrm{SD}=0.32 \pm 0.38$ and 

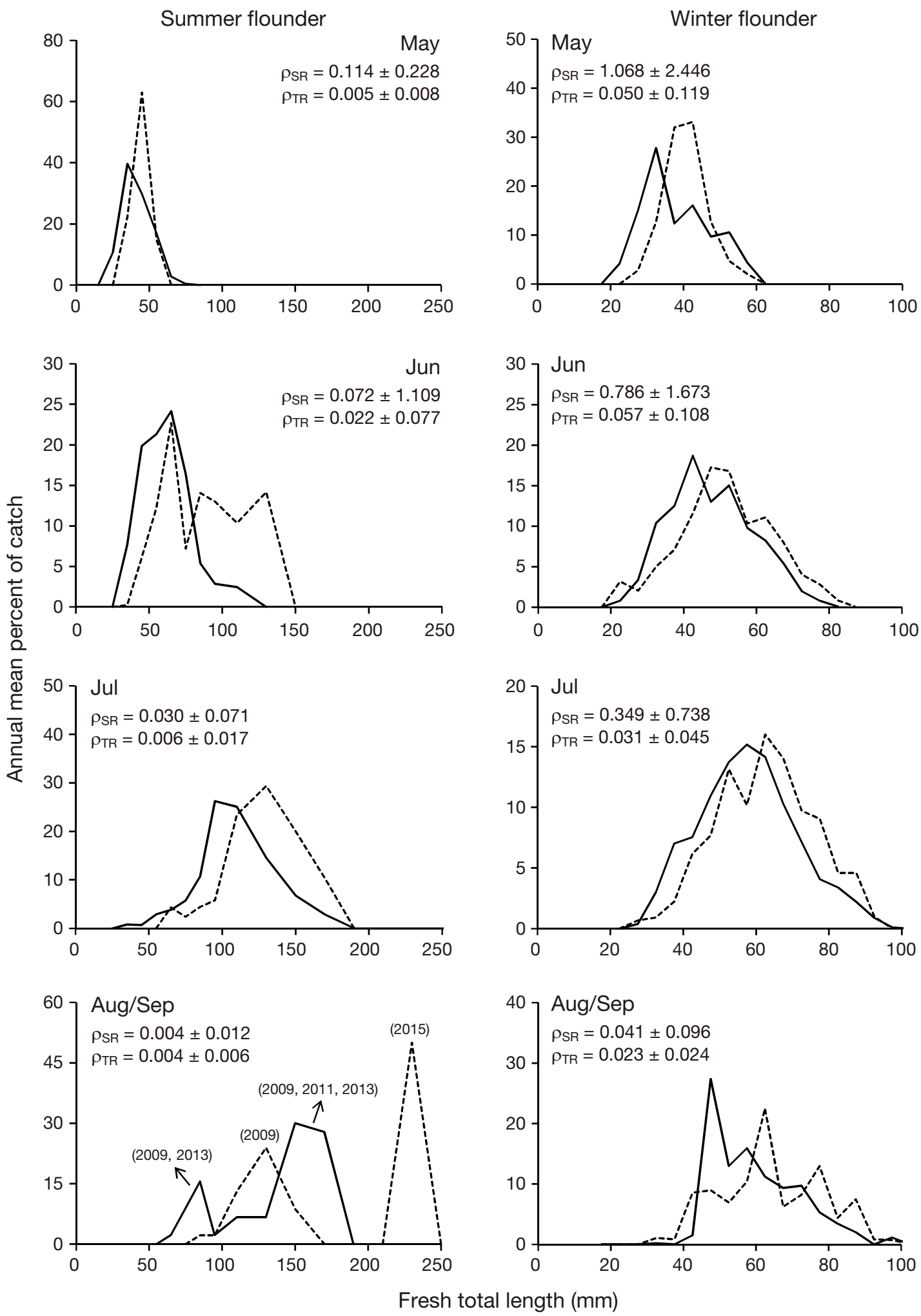

Fig. 2. Monthly length-frequency distributions of summer flounder and winter flounder collected from the Seekonk River (solid line) and Taunton River (dashed line). Lengths represent 'fresh' total length, i.e. measured immediately after capture, and frequencies were calculated as percent of total catch averaged across years (2009-2015). The mean monthly density ( \pm SD) of summer flounder and winter flounder in the Seekonk River $\left(\rho_{\mathrm{SR}}\right)$ and Taunton River $\left(\rho_{\mathrm{TR}}\right)$ are provided. Additionally, collection years are reported in parentheses for summer flounder multi-modal length-frequency distributions in August/September 
Table 3. Model simulations that estimate the total number of winter flounder consumed (WF; no. flounder eaten $\mathrm{m}^{-2}$ ) by summer flounder (SF), and the resulting average and maximum daily instantaneous mortality rate $\left(Z_{\text {avg }}\right.$ and $Z_{\text {max }}$, respectively) and cumulative mortality rate $\left(M_{i} \%\right)$. Simulations were performed separately for the Seekonk and Taunton Rivers for the years 2009 through 2015 and accounted for annual variations in maximum flounder density (no. ind. $\mathrm{m}^{-2}$ ), date of maximum flounder density (day of year [DOY], reported in parentheses), and flounder growth rates $\left(\mathrm{mm}\right.$ fresh total length $\left.\left[\mathrm{TL}_{\mathrm{f}}\right] \mathrm{d}^{-1}\right)$, with the latter affecting predator-to-prey size ratios (Ratio; $\mathrm{SF} \mathrm{mm} \mathrm{TL}_{\mathrm{f}} / \mathrm{WF} \mathrm{mm} \mathrm{TL}_{\mathrm{f}}$ ). Means $\pm \mathrm{SD}$ are reported across years

\begin{tabular}{|c|c|c|c|c|c|c|c|c|c|}
\hline \multirow[t]{2}{*}{ River/Year } & \multicolumn{2}{|c|}{ Maximum density ${ }^{\mathrm{a}}\left(\mathrm{DOY} \mathrm{Y}^{\mathrm{b}}\right)$} & \multicolumn{2}{|c|}{ Growth $^{\mathrm{c}}$} & \multirow[t]{2}{*}{ Ratio $^{c}$} & \multirow{2}{*}{$\begin{array}{c}\text { No. of } \\
\text { WF eaten }\end{array}$} & \multirow[t]{2}{*}{$Z_{\text {avg }}{ }^{\mathrm{d}}$} & \multirow[t]{2}{*}{$Z_{\max }$} & \multirow[t]{2}{*}{$M$} \\
\hline & $\mathrm{SF}$ & WF & $\mathrm{SF}$ & WF & & & & & \\
\hline \multicolumn{10}{|c|}{ Seekonk River } \\
\hline 2009 & $1.05(121)$ & $0.71(37)$ & 0.66 & 0.17 & 1.15 & 1.03 & $6.86 \times 10^{-4}$ & $2.09 \times 10^{-3}$ & 12.83 \\
\hline 2010 & $0.018(131)$ & 0.11 (99) & 1.24 & 0.30 & 2.18 & 0.11 & $8.64 \times 10^{-5}$ & $2.03 \times 10^{-4}$ & 1.34 \\
\hline 2011 & $0.14(131)$ & $0.70(83)$ & 1.26 & 0.28 & 1.93 & 0.22 & $1.65 \times 10^{-4}$ & $5.68 \times 10^{-4}$ & 2.74 \\
\hline 2012 & $0.047(124)$ & $0.37(58)$ & 1.26 & 0.23 & 1.91 & 0.54 & $3.14 \times 10^{-4}$ & $6.62 \times 10^{-4}$ & 6.79 \\
\hline 2013 & $0.45(126)$ & $18.7(94)$ & 1.18 & 0.36 & 1.87 & 0.37 & $2.81 \times 10^{-4}$ & $1.44 \times 10^{-4}$ & 4.64 \\
\hline 2014 & $0.53(142)$ & $0.45(64)$ & 1.58 & 0.18 & 2.18 & 0.14 & $9.65 \times 10^{-5}$ & $9.44 \times 10^{-4}$ & 1.79 \\
\hline 2015 & 0.029 (138) & $0.73(106)$ & 1.30 & 0.41 & 1.68 & 0.053 & $4.20 \times 10^{-5}$ & $1.33 \times 10^{-4}$ & 0.66 \\
\hline \multirow[t]{2}{*}{ Mean $\pm \mathrm{SD}$} & $0.32 \pm 0.38$ & $3.11 \pm 6.88$ & 1.21 & 0.28 & 1.84 & 0.35 & $2.39 \times 10^{-4}$ & $8.64 \times 10^{-4}$ & 4.40 \\
\hline & $(130.4 \pm 7.5)$ & $(77.3 \pm 25.3)$ & \pm 0.27 & \pm 0.09 & \pm 0.35 & \pm 0.34 & $\pm 2.22 \times 10^{-4}$ & $\pm 7.02 \times 10^{-4}$ & \pm 4.28 \\
\hline \multicolumn{10}{|c|}{ Taunton River } \\
\hline 2009 & 0.69 (123) & $0.030(89)$ & 0.92 & 0.36 & 1.46 & 0.69 & $6.20 \times 10^{-4}$ & $2.25 \times 10^{-3}$ & 8.64 \\
\hline 2010 & 0.00 & $0.008(121)$ & - & 0.47 & - & 0 & 0 & 0 & 0 \\
\hline 2011 & $0.011(139)$ & $0.064(150)$ & 2.24 & 0.47 & 2.33 & 0.004 & $1.66 \times 10^{-6}$ & $2.11 \times 10^{-5}$ & 0.05 \\
\hline 2012 & $0.016(134)$ & $0.11(84)$ & 2.06 & 0.40 & 2.08 & 0.022 & $1.56 \times 10^{-5}$ & $6.19 \times 10^{-5}$ & 0.27 \\
\hline 2013 & $0.012(122)$ & 0.49 (65) & 1.22 & 0.24 & 2.02 & 0.025 & $1.66 \times 10^{-5}$ & $5.41 \times 10^{-5}$ & 0.31 \\
\hline 2014 & $0.011(142)$ & $0.046(81)$ & 1.86 & 0.29 & 2.07 & 0.049 & $3.55 \times 10^{-5}$ & $9.73 \times 10^{-5}$ & 0.62 \\
\hline 2015 & $0.002(142)$ & $0.091(77)$ & 2.45 & 0.31 & 2.41 & 0.051 & $3.04 \times 10^{-5}$ & $7.60 \times 10^{-5}$ & 0.63 \\
\hline \multirow[t]{2}{*}{ Mean $\pm \mathrm{SD}$} & $0.11 \pm 0.26$ & $0.12 \pm 0.17$ & 1.79 & 0.36 & 2.06 & 0.12 & $1.03 \times 10^{-4}$ & $3.66 \times 10^{-4}$ & 1.50 \\
\hline & $(133.7 \pm 9.1)$ & $(88.8 \pm 18.6)$ & \pm 0.60 & \pm 0.09 & \pm 0.33 & \pm 0.25 & $\pm 2.29 \times 10^{-4}$ & $\pm 8.33 \times 10^{-4}$ & \pm 3.16 \\
\hline $\begin{array}{l}{ }^{a} \text { Maximum fl } \\
\text { time }(t)(\mathrm{Eq} . \\
\text { the day of ye } \\
(\mathrm{Eq} .2)_{;}{ }^{\mathrm{C}} \mathrm{Flou} \\
141 \text { to } 253) ; \\
\text { size was } 8 \mathrm{~m}\end{array}$ & $\begin{array}{l}\text { der densities } \\
\text { ates of maxi } \\
\text { n which sun } \\
\text { growth rate } \\
\text { ter flounder } \\
L_{f} \text { (Eq. 2) to I }\end{array}$ & $\begin{array}{l}\text { num flounder } \\
\text { mer flounder } \\
\text { (Eq. 3) and pr } \\
\text { average daily i } \\
\text { ay } 253\end{array}$ & $\begin{array}{l}\text { sities n } \\
\text { e } 13 \mathrm{~m} \\
\text { ator-to- } \\
\text { antanec }\end{array}$ & $\begin{array}{l}\mathrm{TL}_{\mathrm{f}} \text { an } \\
\text { ey size } \\
\text { s morta }\end{array}$ & $\begin{array}{l}\text { led by } \\
\text { inter fl } \\
\text { os were } \\
\text { rates w }\end{array}$ & $\begin{array}{l}\text { back-cal } \\
\text { lounder } \\
\text { e averag } \\
\text { vere calc }\end{array}$ & $\begin{array}{l}\text { ating intrasp } \\
\text { from May } 21 \\
\text { ted from the }\end{array}$ & $\begin{array}{l}\text { Sic growth } \mathrm{m} \\
\text { September } \\
\text { y of year me }\end{array}$ & $\begin{array}{l}\text { over } \\
\text { els to } \\
\text { nent) } \\
\text { Days } \\
\text { body }\end{array}$ \\
\hline
\end{tabular}

$0.11 \pm 0.26$ flounder $\mathrm{m}^{-2}$, respectively; K-S $=2.659, \mathrm{p}<$ 0.0001; Fig. 3A). Further, maximal summer flounder densities occurred in early and mid-May, and these temporal patterns were consistent across rivers and years (DOY of maximum density in Seekonk and Taunton Rivers $=130.4 \pm 7.5$ and $133.7 \pm 9.1$, respectively).

Winter flounder population densities were maximal in 2013 in the Seekonk and Taunton Rivers (18.7 and 0.49 ind. $\mathrm{m}^{-2}$, respectively) and, similar to summer flounder, abundances were significantly higher in the former river $\left(3.11 \pm 6.88\right.$ and $0.12 \pm 0.17$ ind. $\mathrm{m}^{-2}$, respectively; K-S = 3.315, p < 0.0001; Table 3, Fig. 3B). The timing of peak winter flounder densities occurred earlier in the season relative to summer flounder, i.e. mid- to late March, and settlement patterns were substantially more variable across rivers and years (DOY of maximum density in Seekonk and Taunton Rivers = $77.3 \pm 25.3$ and $88.8 \pm 18.6$, respectively).

The logarithmic regression models adequately fit the flounder body size data measured during field sampling (May through August/September; Fig. 3C,D), as indicated by statistically significant model fits (mean $\mathrm{p}<0.005$; range $<0.05$ to $<0.0001$ ) and relatively high $\mathrm{R}^{2}$ values (mean $\mathrm{R}^{2}=0.722$; range $=0.279-0.989$ ), irrespective of species, river, or year. The mean annual growth rate of summer flounder in the Seekonk and Taunton Rivers was $1.21 \pm 0.27$ and $1.79 \pm 0.60 \mathrm{~mm} \mathrm{~d}^{-1}$, respectively (range $=0.66-2.54 \mathrm{~mm} \mathrm{~d}^{-1}$ ), whereas winter flounder growth was comparatively slower in the respective rivers $\left(0.28 \pm 0.09\right.$ and $0.36 \pm 0.09 \mathrm{~mm} \mathrm{~d}^{-1}$; range $=0.17-0.47 \mathrm{~mm} \mathrm{~d}^{-1}$; Table 3 ). Intraspecific flounder growth rates did not differ between the Seekonk and Taunton Rivers, i.e. day-river interaction effects were not significant $(\mathrm{ANCOVA}$ day $\times$ river; summer flounder: $F_{1,132}=0.06, \mathrm{p}=0.800$; winter flounder: $F_{1,202}=1.30, \mathrm{p}=0.256$ ). However, the mean TL $\left(\mathrm{TL}_{\mathrm{f}, t}\right.$ ) of both flounder species at time $t$ (DOY) was significantly larger for individuals collected from the Taunton River (ANCOVA; river; summer flounder: $F_{1,132}=7.47, \mathrm{p}<0.01$; winter flounder: $F_{1,202}=15.9, \mathrm{p}<$ 

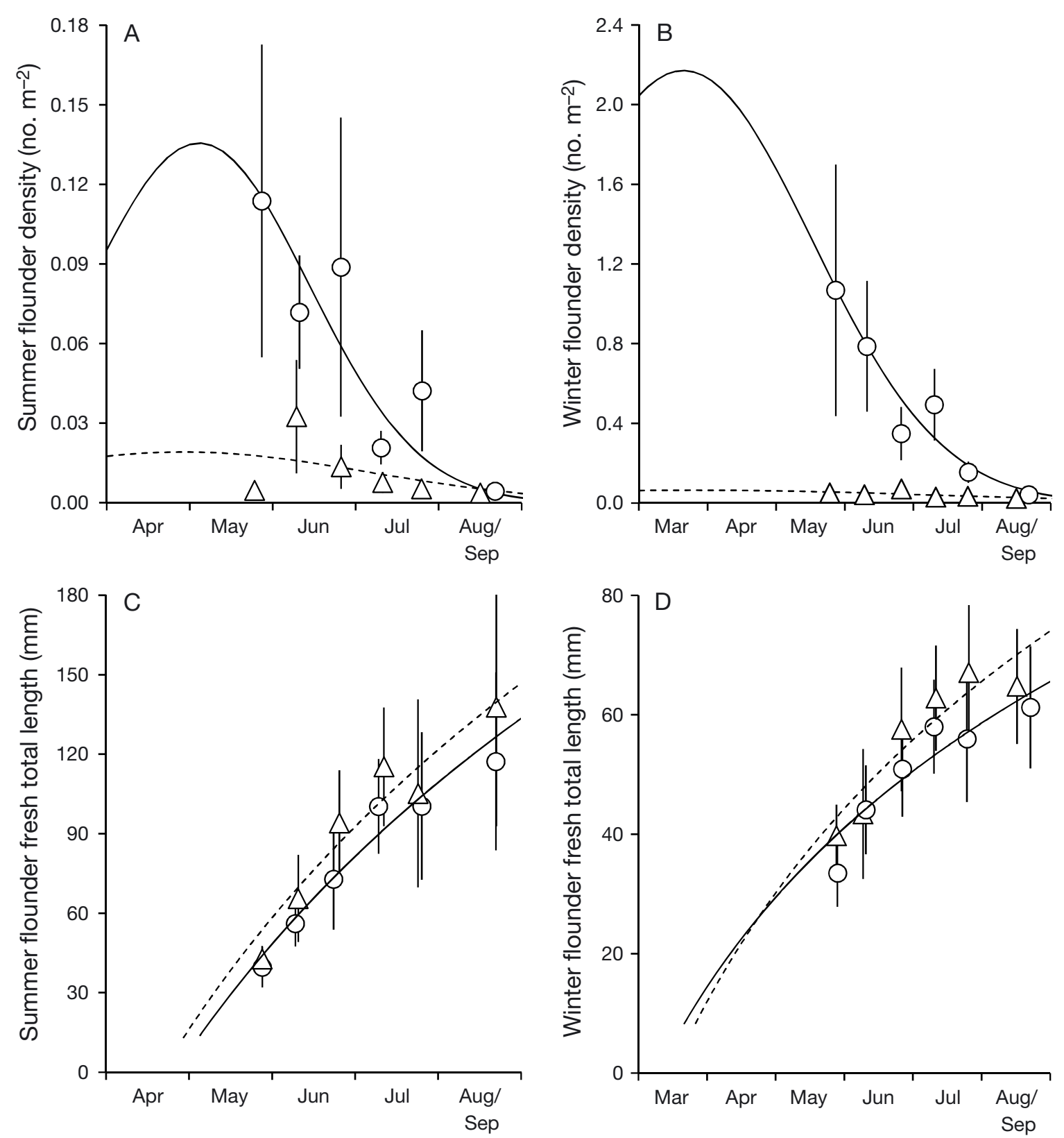

Fig. 3. (A,B) Monthly densities and (C,D) 'fresh' total lengths of summer flounder and winter flounder, respectively, collected from the Seekonk River (circles) and Taunton River (triangles). Data points represent means calculated across river sites (see Fig. 1) and years (2009-2015), and error bars denote \pm SE. Normal density functions (Eq. 1) and logarithmic regression models (Eq. 2) were fit to full data sets for the Seekonk River (solid lines) and Taunton River (dashed lines). The dates of maximum flounder densities were determined by back-calculating intraspecific growth models to the day of year on which summer flounder were $13 \mathrm{~mm}$ and winter flounder were $8 \mathrm{~mm}$ (i.e. size at settlement; Able \& Fahay 2010)

0.0001; Fig. 3C,D). Moreover, for each river, intraspecific flounder growth rates were reevaluated from May through mid-July, as opposed to August/September being the terminal date. This truncated time interval eliminates or minimizes size-dependent processes that potentially confound the original growth results (e.g. emigration of late season, larger-bodied flounder; Rountree \& Able 1992, Szedlmayer et al. 1992). This reanalysis yielded very similar growth patterns. First, summer flounder grew significantly faster than winter flounder in both rivers $\left(\mathrm{ANCOVA}_{\text {; }}\right.$ day $\times$ species; Seekonk: $F_{1,139}=26.45, \mathrm{p}<0.0001$; Taunton: $F_{1,90}=$ $10.44, \mathrm{p}<0.005)$. Second, mean $\mathrm{TL}_{\mathrm{f}, t}$ values at time $t$ were significantly greater for Taunton River flounder (ANCOVA; river; summer flounder: $F_{1,97}=10.69, \mathrm{p}<$ 0.005 ; winter flounder: $F_{1,131}=5.15, \mathrm{p}<0.05$ ). 
Intraspecific logarithmic growth models were used to calculate predator-to-prey size ratios (mean summer flounder $\mathrm{TL}_{\mathrm{f}} /$ mean winter flounder $\mathrm{TL}_{\mathrm{f}}$ ) as a function of DOY. Accordingly, the mean flounder predator-to-prey size ratio, calculated from late May to early September, was $1.94 \pm 0.35$ (range $=1.15-$ 2.41; Table 3 ). The respective size discrepancy between flounder species significantly increased over time (ANCOVA; day: $F_{1,109}=34.1, \mathrm{p}<0.0001$ ), and was attributed to the faster growth rates of summer flounder relative to winter flounder (Table 3). Finally, seasonally calculated predator-to-prey size ratios were lower in the Seekonk River relative to the Taunton River (mean $\pm \mathrm{SD}=1.84 \pm 0.35$ and $2.06 \pm$ 0.33 , respectively), but these differences were not significant (ANCOVA; river: $F_{1,109}=1.85, \mathrm{p}=0.177$ ).

\subsection{Visual analysis of summer flounder diet}

A total of 743 summer flounder from the Seekonk River (SR) and Taunton River (TR) were randomly selected for stomach content analysis (SR: $\mathrm{n}=514$, 20-171 mm TL $\mathrm{m}_{\mathrm{f}}$ TR: $\mathrm{n}=229,32-181 \mathrm{TL}_{\mathrm{f}}$ Table 1). Visual inspection revealed that 101 of these stomachs contained fish prey $(\% F=13.6 \%)$, and 167 individual fish were recovered from the stomach contents $(1.65$ individual fish stomach ${ }^{-1}$ ). In total, 8 unique fish prey taxa were identified in summer flounder stomachs (excluding 'unidentified' fish), and $94.9 \%$ of these stomachs only contained a single fish taxon (1.05 taxa stomach $^{-1}$ ).

Summer flounder predation on fish exhibited considerable spatiotemporal variation. For example, summer flounder from the Seekonk River had a broader dietary breadth then conspecifics from the Taunton River ( 7 and 4 fish prey taxa consumed, respectively; Table 1). The overall occurrence of fish in the summer flounder diet, however, was greater in the Taunton River ( $\% F$ : TR $=17.0 \%$; $\mathrm{SR}=12.1 \%$, respectively), and predation on fish was markedly higher in the upper reaches of both rivers in comparison to other field sites $(\% F$ : TR $1=26.7 \%$; SR1 $=$ $21.1 \%$; other sites $=8.8 \%$; Fig. 1). The incidence of fish in summer flounder stomachs was relatively low during May in the Seekonk and Taunton Rivers ( $\% F=2.3 \%)$, after which $\% F$ increased from June through mid-July ( $\% F=18.4 \%$; Fig. 4). Summer flounder predation on fish declined thereafter, remaining relatively constant in the Seekonk River from late July to September ( $\% F \sim 5.5 \%$ ), whereas $\% F$ decreased from 23.3 to $0.0 \%$ in the Taunton River during the same time period.

The majority of fish encountered in the stomachs of summer flounder from the Seekonk and Taunton Rivers were unidentifiable to a specific taxon (unidentified fish $\% F$ : SR $=7.4 \%$; TR $=9.6 \%$; Table 1). Of the visually identifiable fish taxa, the dominant prey of summer flounder from the Taunton River were herring $(\% F=6.1 \%)$, while gobies, pipefish, and silversides were of lesser importance $(\% F=0.4-$ $1.3 \%)$. In the Seekonk River, winter flounder were the most common fish type in the diet of summer flounder $(\% F=3.3 \%)$, followed by suckers, pipefish, silversides, herring, eels, and largemouth bass $(\% F=$ $0.2-0.6 \%)$. Summer flounder consumed fish prey with a mean $\mathrm{TL}_{\mathrm{p}}$ of $27.4 \pm 7.8 \mathrm{~mm}$ (range $=17.5-$ $55.4 \mathrm{~mm}$; Table 1), and the mean body size of piscivorous summer flounder was $82.0 \pm 26.7 \mathrm{~mm} \mathrm{TL}_{\mathrm{p}}$ (range $=42-172 \mathrm{~mm}$ ).

The summer flounder-winter flounder predatorprey interaction varied spatially and temporally

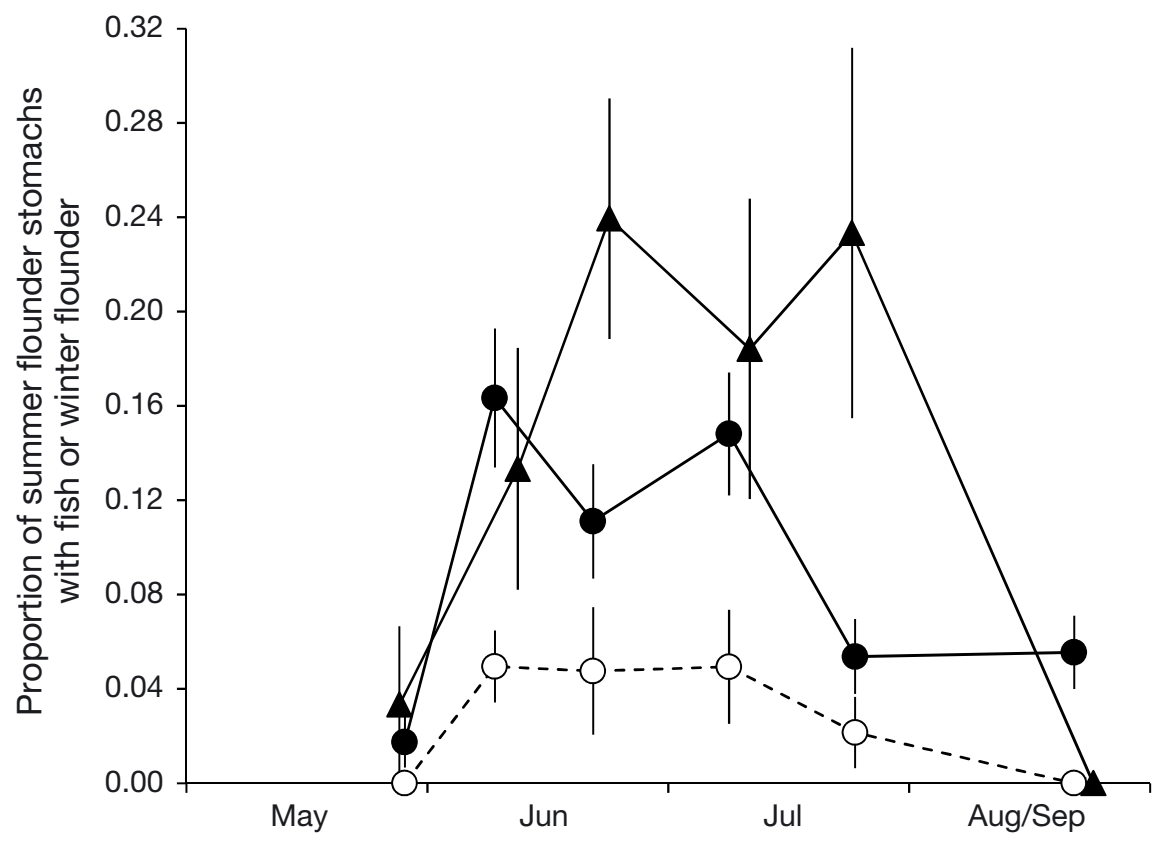

Fig. 4. Proportion of summer flounder stomach contents containing fish prey (solid symbols) or winter flounder (open symbols) from the Seekonk River (circles; $\mathrm{n}=$ 514) and Taunton River (triangles; $\mathrm{n}=229$ ). Data were grouped by months, and means were calculated across river sites (see Fig. 1) and years (2009-2015). Error bars denote $\pm \mathrm{SE}$ 
(Table 1, Fig. 4), such that predation rates on winter flounder were maximal in the upper portion of the Seekonk River $(\% F$ : SR1 $=7.8 \%$; other sites $=$ $0.0-1.4 \%$ ) and during June ( $\% F$ : June $=4.8 \%$; other months $=0.0-3.4 \%$ ). Summer flounder predation on winter flounder was not directly observed in the Taunton River.

\subsection{Molecular genetic analysis of summer flounder diet}

DNA concentrations (mean $\pm \mathrm{SD}$ ) varied by tissue type and were highest in field-collected summer flounder and non-target prey $\left(83.5 \pm 216.1 \mathrm{ng} \mathrm{hl}^{-1}\right.$; $\mathrm{n}=16$ ), followed by non-consumed winter flounder $\left(70.0 \pm 84.7 \mathrm{ng} \mathrm{hl}^{-1} ; \mathrm{n}=7\right)$, consumed unidentified fish $\left(63.1 \pm 75.0 \mathrm{ng} \mathrm{ul}^{-1} ; \mathrm{n}=60\right)$, and consumed winter flounder $\left(22.1 \pm 38.2 \mathrm{ng} \mathrm{\mu l}^{-1} ; \mathrm{n}=17\right)$. DNA quality values (A260/A280) were comparable across tissue types $(1.94 \pm 0.27$; range $=0.88-3.20)$. The speciesspecific primer set used in this study (WF208; Collier et al. 2014) consistently amplified DNA from fieldcollected (non-consumed) winter flounder, and conversely, no amplification occurred for field-collected summer flounder or non-target fish and invertebrate prey. With respect to prey recovered from summer flounder stomachs, PCR products were observed in $58.8 \%$ of the consumed winter flounder (10 of 17 samples), and $3.3 \%$ of the unidentified fish prey resulted in amplification of target DNA (2 of 60 samples). Sequencing of select PCR products confirmed that the WF208 primer set amplified the expected region of the winter flounder DNA for all tissue types ( 7 of 7 samples; GenBank accession number U12068.1).

\subsection{Flounder morphological relationships}

The linear and exponential regression models used to examine morphological relationships in summer flounder and winter flounder (Eqs. 4-8) were highly significant (mean $\mathrm{R}^{2}=0.98$, range $=0.92-1.00$; $\mathrm{p}<$ 0.0001 ; Table 2). For the winter flounder $\mathrm{TL}_{\mathrm{p}}-\mathrm{OL}$ regression (Eq. 6), ANCOVA models were used to examine the effect of river (Seekonk and Taunton) and year (2011 through 2013) on the relationship. As neither discrete explanatory variable significantly affected the $\mathrm{TL}_{\mathrm{p}}-\mathrm{OL}$ model (ANCOVA; river: $F_{1,50}=$ $0.25, \mathrm{p}=0.619$; year: $\left.F_{2,50}=0.25, \mathrm{p}=0.778\right)$, data were pooled for further analysis (Fig. 5A). A total of 21 winter flounder were recovered from 17 summer
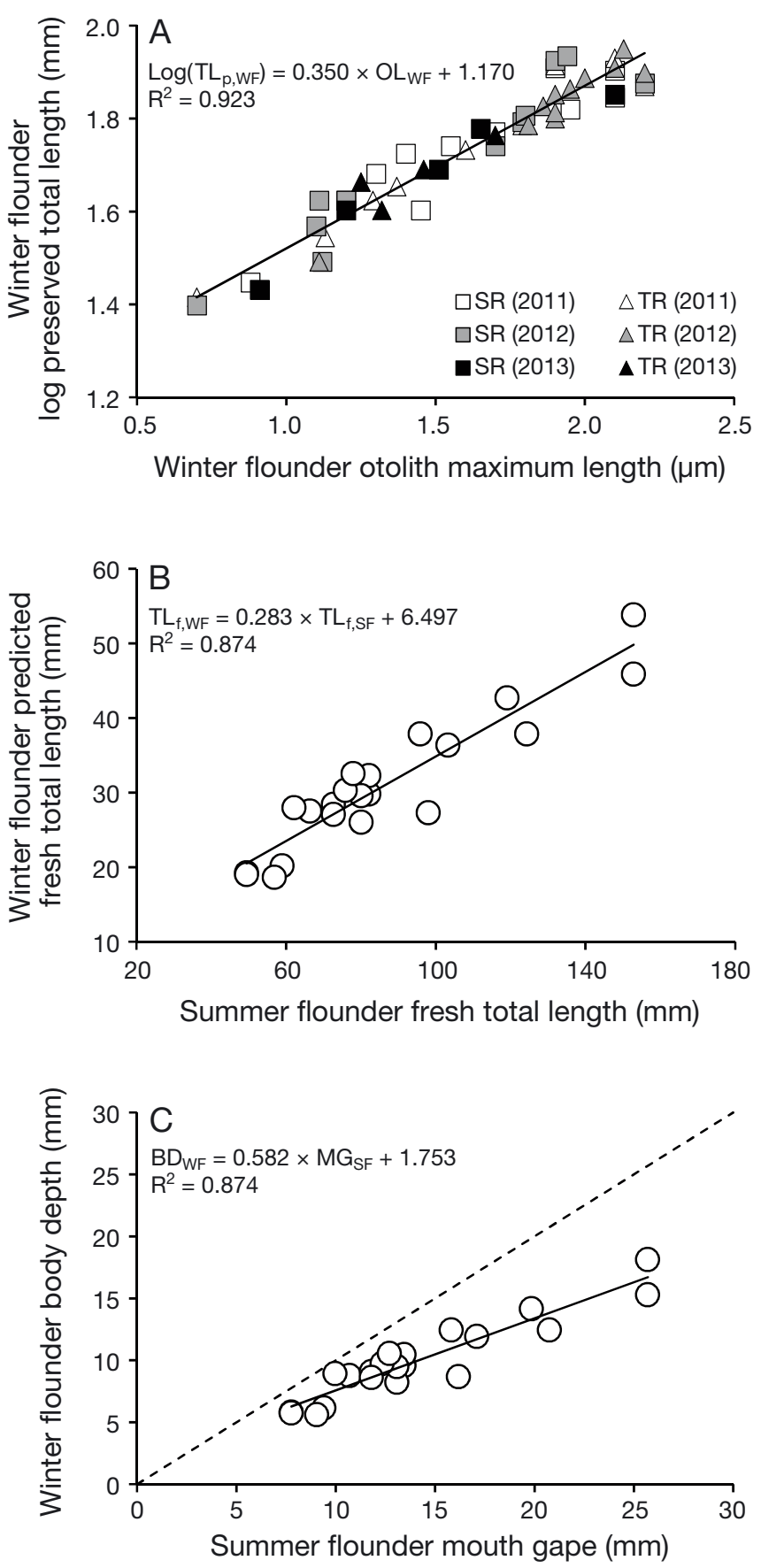

Fig. 5. (A) Relationship between the maximum linear length of sagittal otoliths (OL) and preserved total length (log-transformed; $\mathrm{TL}_{\mathrm{p}}$ ) of winter flounder (WF) collected from the Seekonk River (SR) and Taunton River (TR) from 2011 through 2013 ( $\mathrm{n}=51)$. (B) Relationship between the fresh total length $\left(\mathrm{TL}_{\mathrm{f}}\right)$ of summer flounder $(\mathrm{SF})$ and predicted $\mathrm{TL}_{\mathrm{f}}$ of consumed winter flounder $(\mathrm{n}=21)$. (C) Relationship between the predicted mouth gape of summer flounder (MG) and body depth of consumed winter flounder (BD) $(n=21)$. Solid lines represent linear least-squares regression models fit to the full data sets with the equations and $R^{2}$-values provided, and the dashed line represents the flounder MG-to-BD 1:1 ratio 
flounder stomachs (1.24 winter flounder stomach $\left.{ }^{-1}\right)$, and the mean number of predatory events per year was $4.0 \pm 3.2$ (range $=1-9$, as observed in 2013 and 2011, respectively). The mean $\mathrm{TL}_{\mathrm{f}}$ of consumed winter flounder equaled $31.0 \pm 9.1 \mathrm{~mm}$ (range $=$ 18.7-53.8 mm), as determined from Eqs. (5) and (6). The predatory summer flounder had a mean body size of $86.3 \pm 29.9 \mathrm{~mm} \mathrm{TL}_{\mathrm{f}}$ (range $=49.5-152.8 \mathrm{~mm}$; converted from $\mathrm{TL}_{\mathrm{p}}$ using Eq. 4), resulting in a mean predator-to-prey size ratio of $2.77 \pm 0.34$ (range $=$ $2.22-3.59$ ). There was a significant positive relationship between the $\mathrm{TL}_{\mathrm{f}}$ of summer flounder visually confirmed to feed on winter flounder and the predicted $\mathrm{TL}_{\mathrm{f}}$ of winter flounder recovered from summer flounder stomachs (linear regression: $F=132.2, \mathrm{R}^{2}=$ 0.874, p $<0.0001$; Fig. 5B).

Summer flounder that preyed on winter flounder had an estimated mean MG of $14.2 \pm 4.4 \mathrm{~mm}$ (range = 7.8-25.7 mm; Eq. 7), and the mean BD of the consumed winter flounder was $10.0 \pm 2.2 \mathrm{~mm}$ (range $=$ 5.6-18.1 mm; Eq. 8). Increases in summer flounder MG as a function of their $\mathrm{TL}_{\mathrm{f}}$ resulted in the consumption of larger-bodied winter flounder, yet winter flounder BD never exceeded the MG of predatory summer flounder (Fig. 5C).

\subsection{Factors affecting summer flounder predation on fish and winter flounder}

The prevalence of fish in the diet of summer flounder was directly related to predator body size

Table 4. Summary statistics and mean parameter estimates for logistic regression analysis of the proportion $(P)$ of summer flounder (SF) stomachs containing fish or winter flounder, as a function of summer flounder fresh total length $\left(\mathrm{TL}_{\mathrm{f}} \mathrm{mm}\right)$, day of year (DOY) $(t)$, salinity $(S)$, summer flounder density ( $\rho$; no. flounder $\mathrm{m}^{-2}$ ), and predator-to-prey size ratio $\left(R_{i}\right.$ summer flounder $\mathrm{mm} \mathrm{TL} / \mathrm{f} /$ winter flounder $\left.\mathrm{mm} \mathrm{TL}_{\mathrm{f}}\right)$. Proportions are the natural logarithm of the ratio of response frequencies (logits); logit

$$
(P)=\log [P / 1-P)]
$$

\begin{tabular}{|lcccc|}
\hline Prey type / Variable & Symbol & $\begin{array}{c}\text { Parameter } \\
\text { estimate (SE) }\end{array}$ & $\begin{array}{c}\text { Chi- } \\
\text { squared }\end{array}$ & $\mathrm{p}$ \\
\hline Fish & & & & \\
$\quad$ SF total length & $\mathrm{TL}_{\mathrm{f}}$ & $0.041(0.006)$ & 49.6 & $<0.0001$ \\
DOY & $t$ & $-0.049(0.009)$ & 33.1 & $<0.0001$ \\
Salinity & $S$ & $-0.113(0.034)$ & 10.9 & $<0.001$ \\
SF density & $\rho$ & $-1.532(0.687)$ & 5.0 & $<0.05$ \\
Intercept & $\alpha$ & $4.444(1.219)$ & 13.3 & $<0.0005$ \\
Winter flounder & & & & \\
Size ratio & $R$ & $1.695(0.448)$ & 14.3 & $<0.0005$ \\
Salinity & $S$ & $-0.161(0.075)$ & 4.7 & $<0.05$ \\
Intercept & $\alpha$ & $-5.245(0.814)$ & 41.5 & $<0.0001$ \\
\hline
\end{tabular}

(Fig. 6A). There was an absence of fish in the stomachs of summer flounder $<44 \mathrm{~mm} \mathrm{TL}_{\mathrm{f}}$, whereas piscine prey were progressively more common in larger summer flounder (maximum $\mathrm{TL}_{\mathrm{f}}=181 \mathrm{~mm} ; \beta=$ 0.041 ; Table 4 ). The probability of fish occurring in summer flounder stomachs was also inversely related to DOY $(t ; \beta=-0.049)$ and predator density $\left(\rho_{\mathrm{SF} ;} \beta=\right.$ -1.532 ) (Table 4). These results may be attributed indirectly to body size effects, given that larger summer flounder occur later in the season when densities are also reduced (Figs. 2 \& 3A,C). Finally, summer flounder predation on fish increased at lower salinities $\left(S_{\text {; }}\right.$ $\beta=-0.113$; Fig. $6 \mathrm{~B})$, as indicated by the high $\% F$ values observed in the upper reaches of the Seekonk and Taunton Rivers (i.e. oligohaline water; Table 1).

Summer flounder predation on winter flounder was significantly related to the predator-to-prey size ratios (Fig. 6C), such that increases in summer flounder $\mathrm{TL}_{\mathrm{f}}$, relative to winter flounder lengths, coincided with higher probabilities of predation $(R ; \beta=1.695$; Table 4). The occurrence of winter flounder in summer flounder stomachs was also inversely related to salinity ( $\beta=-0.161$; Table 4 , Fig. $6 \mathrm{D})$, again reflecting the higher $\% F$ values at the oligohaline sites in the Seekonk River (Table 1).

\subsection{Modeling winter flounder mortality owing to summer flounder predation}

Model simulations (2009 through 2015) estimated that summer flounder consume, on average, a total of 0.35 winter flounder $\mathrm{m}^{-2}$ in the Seekonk River (range $=0.05-1.03$ winter flounder $\mathrm{m}^{-2}$; Table 3 ). This corresponds to a mean annual cumulative mortality $(M)$ of $4.4 \%$ (range $=0.7-12.8 \%)$ and average daily instantaneous mortality $\left(Z_{\text {avg }}\right)$ of $2.39 \times$ $10^{-4}$ (range $=4.20 \times 10^{-5}$ to $6.86 \times 10^{-4}$ ) . The predatory impact of summer flounder was lower in the Taunton River, with 0.12 winter flounder consumed $\mathrm{m}^{-2}$ (mean) during the observation period (range $=0.0-0.69$ winter flounder $\mathrm{m}^{-2}$; Table 3). This predation rate equates to a mean $M$ of $1.5 \%$ (range $=0.0-8.6 \%$ ) and $Z_{\text {avg }}$ of $1.03 \times 10^{-4}$ (range $=0.0$ to $6.20 \times$ $10^{-4}$ ). The total daily instantaneous mortality rate of post-settlement winter flounder was previously reported between 0.0123 and 0.0400 (average $Z=0.0235$; Taylor 2005a and references therein). Thus, on average, in the Seekonk and 

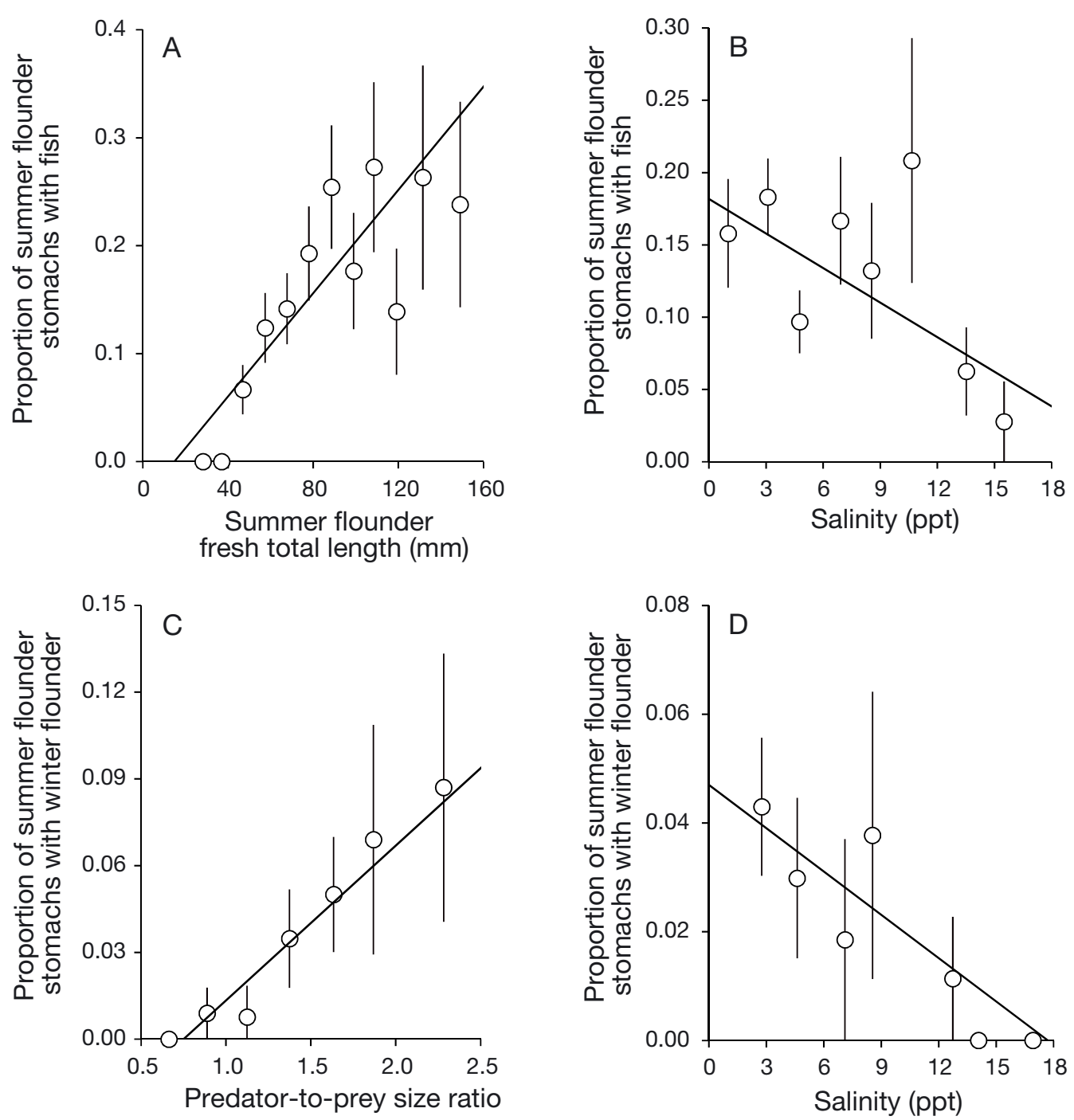

Fig. 6. Proportion of summer flounder stomach contents containing $(A, B)$ fish or $(C, D)$ winter flounder. Occurrences of predation were analyzed as a function of $(A)$ summer flounder fresh total length $\left(T_{\mathrm{f}}\right),(\mathrm{B}, \mathrm{D})$ salinity, and $(\mathrm{C})$ predator-to-prey size ratios (individual summer flounder $\mathrm{TL}_{\mathrm{f}} /$ mean winter flounder $\mathrm{TL}_{\mathrm{f}}$ ). Solid lines represent logistic regression models fit to the full data sets $(n=743)$, but data were binned across the $x$-axis for graphical representation. Error bars denote \pm SE. Summary statistics for the logistic regressions are provided in Table 4

Taunton Rivers, respectively, $1.0 \%$ (range $=0.2-2.9 \%$ ) and $0.4 \%$ (range $=0.0-2.6 \%$ ) of the winter flounder's total daily mortality may be attributed directly to summer flounder predation.

Winter flounder cumulative mortality owing to summer flounder predation was evaluated over a broad range of biological and salinity conditions (Fig. 7). The relative size structure of both flounder species substantially affected predation rates. For example, incremental increases in predator-to-prey size ratios caused an acceleration in winter flounder mortality (Fig. 7A). At a salinity of 5 ppt (i.e. upper river conditions), changes in size ratios from 1.0-2.5 and 2.5-4.0 caused winter flounder $M$ to increase by 9.2 and $51.6 \%$, respectively. Salinity also influenced estimates of winter flounder mortality by ostensibly approximating other causative factors that varied along an upriver-downriver gradient. The effect of salinity was marginal in polyhaline waters (19-32 ppt), and more pronounced in mesohaline (6-18 ppt) and oligohaline waters $(<5 \mathrm{ppt})$. For example, at a fixed predator-to-prey size ratio of 2.77 (i.e. mean size ratio observed in this study), a decrease in salinity from 32 to $19 \mathrm{ppt}$ led to a $1.6 \%$ increase in cumulative mortality of winter flounder, whereas declines from 18 to $6 \mathrm{ppt}$ and 5 to 0 ppt increased $M$ by 11.0 and $13.3 \%$, respectively (Fig. 7A). 

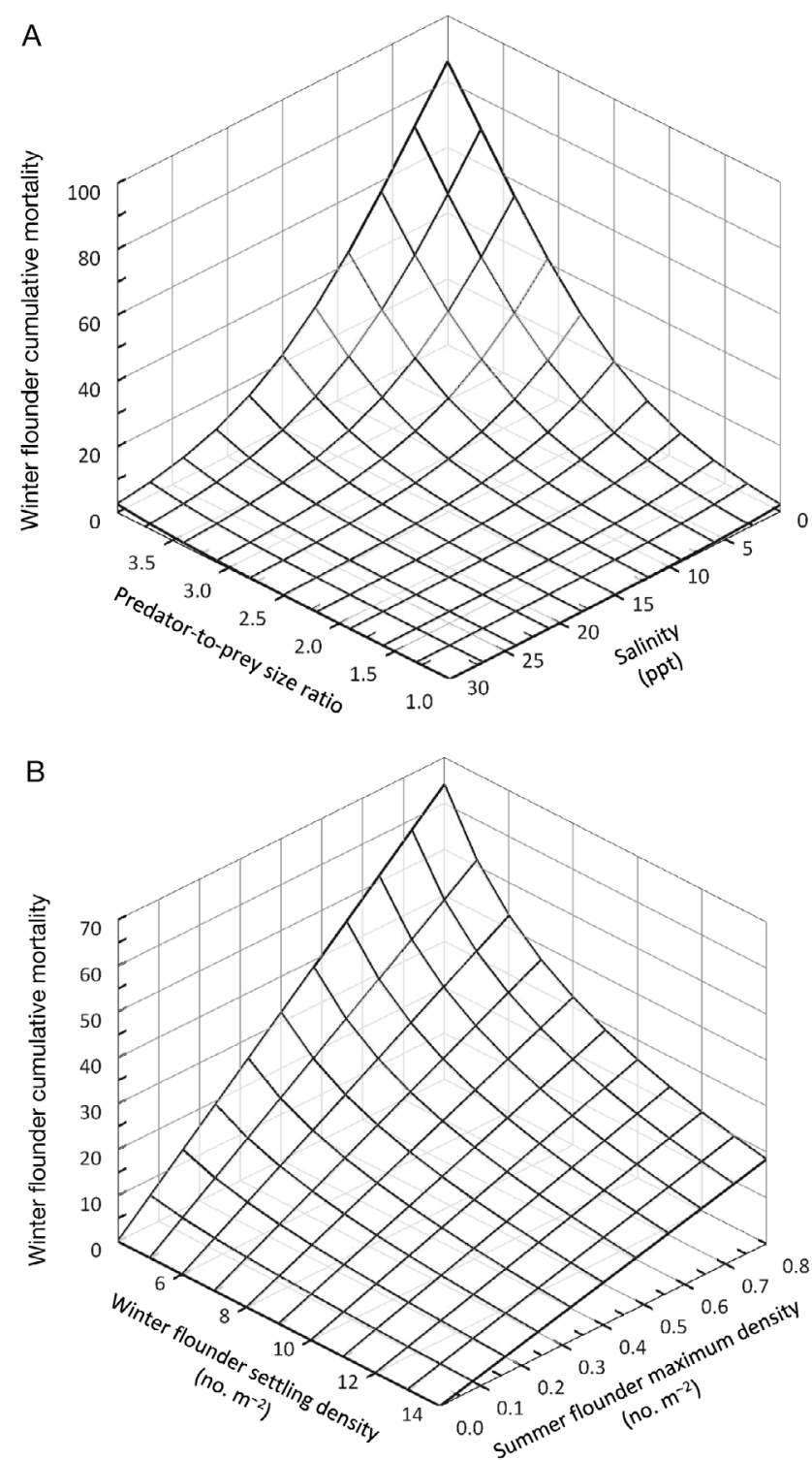

Fig. 7. Winter flounder cumulative mortality $(M)$ owing to summer flounder predation $(M=$ total number of winter flounder eaten by summer flounder $\mathrm{m}^{-2}$ divided by the initial cohort size). Winter flounder mortality was estimated using a deterministic model and calculated over a range of (A) predator-to-prey size ratios (individual summer flounder $\mathrm{TL}_{\mathrm{f}} /$ mean winter flounder $\mathrm{TL}_{\mathrm{f}}$ ) and salinity and (B) winter flounder total cohort size and summer flounder maximum density

Interspecific flounder population dynamics also greatly affected winter flounder predator-induced mortality (Fig. 7B). For example, winter flounder settling at low densities (total cohort $=4$ flounder $\mathrm{m}^{-2}$; $\rho_{\max }=0.16$ flounder $\mathrm{m}^{-2} ; \sigma=10 ; M=25.9 \%$ ) experienced a $18.5 \%$ increase in $M$ relative to conspecifics at higher densities (total cohort $=14$ flounder $\mathrm{m}^{-2}$; $\rho_{\max }=0.56$ flounder $\mathrm{m}^{-2} ; \sigma=10 ; M=7.4 \%$ ), assuming a maximum summer flounder density of $0.323 \mathrm{~m}^{-2}$ (i.e. annual mean in the Seekonk River; Table 3). Moreover, a change in maximum summer flounder density $\left(\rho_{\max }\right)$ from 0.01 to 0.80 ind. $\mathrm{m}^{-2}$ caused a concomitant increase in winter flounder $M$ from 0.4 to $32.1 \%$ (initial winter flounder cohort size $=8$ ind. $\mathrm{m}^{-2}$ ).

\section{DISCUSSION}

\subsection{Summer flounder predation on fishes}

This study provides a detailed description of the piscivorous diet of juvenile (age-0) summer flounder to better understand their trophodynamic role in southern New England tidal rivers. Summer flounder in these rivers exhibited a generalist foraging strategy, consuming 8 distinct fish taxa. The most frequently observed fishes in the diet of summer flounder were winter flounder and herring, with fewer occurrences of pipefish, suckers, silversides, gobies, eels, and bass. The fishes consumed by summer flounder were categorized as age-0 juveniles based on their small body sizes (Jacobs \& O'Donnell 2009, Able \& Fahay 2010), with the exception of gobies that mature at $\sim 20 \mathrm{~mm}$ TL (e.g. naked goby Gobiosoma bosc; Able \& Fahay 2010). These results indicate that age-0 summer flounder consume early-stage fishes from both epibenthic and pelagic prey guilds, as reported for older conspecifics (Manderson et al. 2000, Staudinger \& Juanes 2010a). To our knowledge, this study represents the first documentation of piscivory by age-0 summer flounder in southern New England waters (Taylor \& Gervasi 2017).

The piscivorous behavior of age-0 summer flounder described herein is consistent with reports from the Middle and South Atlantic Bight (Packer et al. 1999), although geographic differences in diet composition are evident and attributed to broad spatial variations in fish prey assemblages (Taylor \& Gervasi 2017). For example, in the Great Bay-Little Egg Harbor Estuary (New Jersey), the dominant piscine prey of summer flounder 167-305 mm TL $(\mathrm{n}=137)$ were Atlantic silverside and mummichog $(\% F=32$ and $16 \%$, respectively), whereas striped killifish, sheepshead minnow Cyprinodon variegatus, and naked goby were encountered less frequently (\%F 1\%) (Rountree \& Able 1992). In the York River (Virginia), a major tributary of the Chesapeake Bay, fish were the main dietary item of summer flounder 98-192 mm TL ( $\mathrm{n}=28$; TL converted from standard length, SL; Able \& Fahay 1998), but no further taxonomic resolution of fish prey was provided beyond 
the infraclass Teleostei (Smith et al. 1984). For summer flounder $<225 \mathrm{~mm}$ TL collected from the Chesapeake Bay mainstem $(n=128)$, engraulids (bay anchovy Anchoa mitchilli) and sciaenids (weakfish Cynoscion regalis, Atlantic croaker Micropogonias undulatus, and spot Leiostomus xanthurus) accounted for $\sim 12 \%$ of the total diet (Latour et al. 2008). Similarly, in the Pamlico Sound (North Carolina), fishes occurred frequently in the stomachs of summer flounder 100-200 mm TL ( $\% F=33 \%$; $=313)$, with the most substantial contributions from engraulids and sciaenids (Powell \& Schwartz 1979).

In our study, the presence of fish in the diet of summer flounder directly corresponded to predator body size. Summer flounder reportedly undergo an ontogenetic transition to fish prey as predator size increases (Festa 1979, Link et al. 2002, Latour et al. 2008, Buchheister \& Latour 2015), and this was attributed to the enlarged mouth gape and improved prey capture abilities of larger flounder (Buchheister \& Latour 2011). Moreover, summer flounder predation on fishes in this study demonstrated significant spatiotemporal variability. These observations are likely due to site-specific differences in summer flounder body size, somatic growth, and the resultant ontogenetic transition to piscivory (Taylor et al. 2016). The diet composition of summer flounder may simultaneously reflect riverine and seasonal variations in prey composition, which affect the feeding habits of this species in other geographic locations (Powell \& Schwartz 1979, Rountree \& Able 1992, Manderson et al. 2000, Link et al. 2002, Latour et al. 2008). With the exception of age-0 winter flounder, the in situ abundance of fishes that constitute important prey of summer flounder were not quantified in this study. Previous investigations in southern New England and mid-Atlantic estuaries, however, have documented habitat-specific and seasonal variations in juvenile fish abundance, most notably herring, Atlantic silverside, northern pipefish, and American eel (Able \& Fahay 1998, 2010). The diet composition of summer flounder ultimately reflects spatiotemporal dynamics in prey availability, as well as morphological constraints imposed by relative predator-prey body sizes (Manderson et al. 2000, Staudinger \& Juanes 2010a).

\subsection{Utility of molecular genetics to identify species-specific prey}

The visual identification of prey species extracted from predator stomachs is often difficult and there- fore hampers our understanding of trophic relationships in natural systems. For example, in this study, the majority of fishes encountered in the stomachs of summer flounder were unrecognizable to a detailed taxon, and 'unidentified fish' routinely accounted for the largest component of the summer flounder diet (\% weight or volume dietary contribution 12-21\%; Festa 1979, Link et al. 2002, Sagarese et al. 2011). The molecular genetic technique used in this study offers a supplementary approach to analyzing predator stomach contents by testing for the presence of intraspecific genomic DNA (Collier et al. 2014). The efficacy of this approach is contingent on minimizing errors in analysis associated with false-positive and false-negative results. The incorrect assertion that target prey are present in a predator's stomach (falsepositivity) is caused by amplification of non-target DNA. In this regard, the WF208 primer set used in this study was extremely effective at generating PCR products for field-collected (non-consumed) winter flounder (100\% amplification) without cross-reacting with the genomic material of the predator or alternative prey (i.e. primers have high sensitivity and specificity; Taylor 2004). Further, sequencing of PCR products confirmed that the WF208 primer set amplified the expected mitochondrial non-coding control region (D-loop) of the winter flounder genome, hence alleviating potential concerns of false-positive results.

The WF208 primers were moderately successful at amplifying the DNA of winter flounder extracted from summer flounder stomachs ( $59 \%$ amplification). The inability to generate PCR products for several of the consumed winter flounder (falsenegativity) was mainly attributed to prolonged digestion and the degradation of target DNA regions (Collier et al. 2014). Although the effect of digestion time on detecting winter flounder DNA in summer flounder stomachs was not quantified in this study (i.e. detection limits; Taylor 2004), previous investigations that used PCR-based methods to evaluate piscivorous fish diets reported detection limits of 12 to $16 \mathrm{~h}$ (Rosel \& Kocher 2002, Carreon-Martinez et al. 2011). Moreover, using the WF208 primer set, Collier et al. (2014) and Scro et al. (2014) amplified juvenile winter flounder DNA 7 and $10 \mathrm{~h}$ after initial ingestion by blue crabs, respectively. False-negative results may have secondarily occurred because of the ineffectiveness of WF208 primers to amplify biological variants of the target winter flounder DNA region, as confirmed by Collier et al. (2014). In our study, 60 summer flounder stomachs contained unidentified fish, as determined by direct visual inspection, and subsequent genetic analyses (PCR and DNA sequencing) 
verified that $3.3 \%$ of these stomach samples contained winter flounder. Given the potential for falsenegativity (e.g. testing beyond detection limits and biological variants), these results are conservative because additional unidentified fish prey may be winter flounder. Notwithstanding these limitations, the genetic techniques employed in this study improved the quantitation of the summer flounderwinter flounder predator-prey interactions.

\subsection{Summer flounder predation on winter flounder}

By coupling stomach content analysis with molecular genetic techniques, this study provides the first evidence of age-0 summer flounder predation on winter flounder in natural populations (Taylor \& Gervasi 2017). Winter flounder occurred in $\sim 3 \%$ of summer flounder stomachs, and predatory events were relatively common in the upper reaches of the Seekonk River $(\% F=\sim 8 \%)$. Several investigations purport that age-1+ summer flounder are important predators of age- 0 winter flounder in more southern estuaries, with occurrences of predation comparable to this study. For example, in the Little Egg Harbor Estuary, winter flounder were present in the diet of $8 \%$ of summer flounder $260-650 \mathrm{~mm}$ TL ( $\mathrm{n}=13$ ) (Festa 1979). Similarly, in the Great South Bay (New York), $5 \%$ of the stomachs of summer flounder 260-649 mm TL contained winter flounder $(\mathrm{n}=141)$ (Sagarese et al. 2011). Other studies have indicated that juvenile winter flounder are a more substantial component of age-1+ summer flounder diet. Most notably, age-0 winter flounder were the dominant piscine prey of summer flounder 252-648 mm TL $(\% F=16 \% ; n=95)$ in the Navesink River (New Jersey) (Manderson et al. 2000). Further, in the more expansive Navesink River/Sandy Hook Bay estuarine system, the annual $\% F$ of winter flounder in age-1+ summer flounder stomachs ranged between 11 and $41 \%(\mathrm{n}=207)$ (Manderson et al. 2006).

Predator-prey relations between age-0 summer flounder and winter flounder in our study were affected by their relative body sizes. Summer flounder specifically consumed winter flounder that were $\sim 28-45 \%$ of the predator's $\mathrm{TL}_{\mathrm{f}}$ (mean $\pm \mathrm{SD}=36.6 \pm$ $4.3 \%$ ), and incidences of predation increased significantly with increasing predator-to-prey size ratios. These results closely correspond to previous laboratory experiments, whereby summer flounder 96$450 \mathrm{~mm}$ TL consistently ate age-0 winter flounder that were $30-40 \%$ of their length (maximum $=48 \%$ )
(Curran \& Able 1998). Similarly, in the Navesink River, a predator-to-prey size ratio of 2.7 was observed between summer flounder (378 mm TL) and winter flounder (140 mm TL; $37 \%$ of predator length) (Manderson et al. 2000). However, in the aforementioned study, interspecific length ratios were typically lower in field-collected flounder, i.e. winter flounder (24-67 mm TL) were $6-19 \%$ of summer flounder length (252-648 mm TL; $\mathrm{n}=60$ ) (Manderson et al. 2000).

Morphological constraints, e.g. mouth gape limitations, are critical factors affecting the predator-prey relationship between age-0 summer flounder and winter flounder. In our study, summer flounder mouth gape increased proportionally with total length and resulted in the consumption of larger winter flounder. Moreover, the body dimensions of ingested winter flounder did not exceed the mouth gape of predatory summer flounder, which is consistent with previous research on the foraging ecology of age-1+ summer flounder (Manderson et al. 2000, Staudinger \& Juanes 2010a). The smallest winter flounder collected in this study was $20 \mathrm{~mm} \mathrm{TL}_{\mathrm{f}}$ with a maximum body depth of $6.1 \mathrm{~mm}$. The smallest summer flounder capable of consuming a winter flounder of this size (i.e. unconstrained by mouth gape) is $41 \mathrm{~mm} \mathrm{TL}_{\mathrm{f}}$. This projected minimum-size threshold is below the smallest summer flounder identified as a predator of winter flounder ( $\left.\sim 0 \mathrm{~mm} \mathrm{TL}_{\mathrm{f}}\right)$, suggesting that other size-dependent factors restrict the predator-prey interaction, including size-specific limitations on a predator's pursuit and handling of mobile flatfish prey (Ellis \& Gibson 1997, Manderson et al. 2000).

Temporal variations in the predator-prey interaction between flounder species were governed by their respective size structure. In this study, predation was maximal during June through mid-July, and conversely, absent in May and August/September. Summer flounder $<50 \mathrm{~mm} \mathrm{TL}_{\mathrm{f}}$ comprised $77 \%$ of the population in May, and their small body size precludes winter flounder as viable prey. Conversely, for summer flounder $\geq 50 \mathrm{~mm} \mathrm{TL}_{\mathrm{f}}$, reduced predation rates in May likely reflect the size-dependent vulnerability of winter flounder (Taylor 2003). Predatory summer flounder rely on vision to employ raptorial attack strategies (Olla et al. 1972, Staudinger \& Juanes 2010b), and in the absence of morphological constraints, winter flounder vulnerability to summer flounder predation increases linearly with prey body sizes ranging from 20-90 mm TL (Manderson et al. 2000). The low predator-induced mortality of small winter flounder in late spring may be due to their relative inconspicuousness to visual predators (Man- 
derson et al. 1999, 2000, Taylor 2003). After May, summer flounder predation on winter flounder increased considerably owing to interspecific growth differences. First, the rapid growth of summer flounder augmented the number individuals that effectively prey on winter flounder. For example, from June through mid-July, $83 \%$ of summer flounder exceeded the predatory minimum-size threshold of $50 \mathrm{~mm} \mathrm{TL}$. Moreover, a substantial discrepancy occurred between predator and prey body sizes at this time, hence intensifying the size-dependent predation mortality of winter flounder. Second, over time, the modest growth of winter flounder led to larger individuals that were likely more conspicuous to visually reliant, piscivorous summer flounder. It follows that winter flounder vulnerability to summer flounder predation would increase beyond mid-July, due to the aforementioned interspecific growth differences, yet there was no evidence of predation during these later months. The absence of predatory events in August/September may be due to reduced winter flounder densities, and thus decreased predatorprey encounters (Manderson et al. 2000). Indeed, in this study, occurrences of winter flounder in summer flounder stomachs was positively related to prey density from June to August/September (logistic regression $_{\text {; }}$ chi-squared $=5.51, \mathrm{p}<0.05$ ), noting that May data were excluded because the majority of summer flounder were too small to prey on winter flounder at this time.

Spatial variations in flounder predator-prey interactions may similarly reflect riverine and site-specific differences in winter flounder densities. Summer flounder predation on winter flounder was most frequent in the oligohaline waters of the Seekonk River (site SR1), but not directly observed in the Taunton River. Mean winter flounder densities across years were $\sim 5$ times greater at SR1 than other Seekonk River sites, and moreover, winter flounder densities were $\sim 12$ times greater in the Seekonk River than in the Taunton River. The elevated densities of winter flounder in the Seekonk River, particularly at SR1, presumably increase interspecific encounters (Manderson et al. 2000), which result in more predation events. The presence of winter flounder in summer flounder stomachs may also vary according to the availability of alternative prey. In a concurrent investigation, Taylor \& Gervasi (2017) documented that mysid shrimp, amphipods, and sand shrimp were preferred prey of summer flounder in the Seekonk and Taunton Rivers, and the heterogeneous distribution of these prey items possibly affects predation dynamics on winter flounder (Manderson et al. 2000). Finally, interspecific predator-prey interactions may respond to spatial variations in habitat structure and complexity. Sediment grain size influences the burial capabilities of post-settlement flatfish, including winter flounder (Phelan et al. 2001, Stoner \& Ottmar 2003), and burial behavior is a concealment strategy to avoid visual predators (Gibson \& Robb 1992, Keefe \& Able 1994, Ryer et al. 2008). Previous laboratory experiments further revealed that age-0 winter flounder experienced lower predation rates by age-1+ summer flounder in the presence of eelgrass Zostera marina and sea lettuce Ulva lactuca (Manderson et al. 2000). These habitat-related factors, however, do not explain spatial differences in the flounder predator-prey interaction in our study because sediments are remarkably consistent between the Seekonk and Taunton Rivers $(\%$ silt-clay $=47.6$ and $48.0 \%$, respectively; Taylor et al. 2016), and anecdotal observations suggest negligible differences in macrophyte densities among riverine sites (D. Taylor pers. obs.).

\subsection{Winter flounder mortality owing to summer flounder predation}

Predator-induced mortality during the early juvenile life stage may determine year-class strength and recruitment success of flatfish (Bailey 1994, Gibson 1994). Model simulations from this study estimated that predation by age- 0 summer flounder, on average, accounted for $0.7 \%$ of the daily mortality of age0 winter flounder in the Seekonk and Taunton Rivers (range $=0.0-2.9 \%$ ), and consumed $3.0 \%$ of the total winter flounder year-class annually (range $=0.0-$ $12.8 \%$ ). Moreover, Taylor et al. (2016) documented that age- 0 summer flounder population densities were significantly greater in the Seekonk and Taunton Rivers relative to adjacent systems, including the Narragansett Bay proper and Rhode Island coastal lagoons (mean monthly densities: rivers $=0.01-0.07$; Bay $=0.0-0.001$; lagoons $=0.001-0.003$ ind. $\mathrm{m}^{-2}$ ). Age-0 summer flounder therefore ostensibly contribute even less to winter flounder mortality in these other areas because of low predator densities.

Relative to other predatory threats, e.g. other demersal fishes and decapod crustaceans, age-0 summer flounder likely have a nominal effect on winter flounder populations in tidal river, shallow-water habitats. For example, striped searobins Prionotus evolans 180-370 mm TL frequently preyed on age-0 winter flounder in the Sandy Hook Bay ( $\% F$ in June $~ 69 \%$; $\mathrm{n}=36$ ), and winter flounder contributed $\sim 18 \%$ by weight to the overall searobin diet (Manderson et al. 
1999). Through the use of PCR-amplification techniques, winter flounder DNA was evident in the diet of $\sim 29 \%$ of blue crabs sampled in the Shinnecock Bay (New York) from July through September (size $>54 \mathrm{~mm}$ carapace width; $\mathrm{n}=42$ ), suggesting that crabs are an important mortality factor for early-stage flounder (Collier et al. 2014). Finally, by implementing a similar modeling approach, Taylor $(2005 a, b)$ predicted that green crabs Carcinus maenas from the Niantic River (Connecticut) and sand shrimp from Narragansett Bay contributed 2 and $25 \%$ to the daily mortality of age- 0 winter flounder and $\sim 10$ and $44 \%$ loss of the total year-class, respectively. The substantial mortality risk imposed by crangonid shrimp, but lesser for portunid crabs, resulted from the common occurrence of winter flounder in predator stomachs ( $\% F=8.5$ and $4.8 \% ; \mathrm{n}=1270$ and 313, respectively) and extremely high densities of shrimp ( $>15$ ind. $\left.\mathrm{m}^{-2}\right)$, and moderate densities of crabs $\left(\sim 0.2\right.$ ind. $\left.\mathrm{m}^{-2}\right)$, in the estuaries (Taylor 2005a,b).

It is noteworthy that the cumulative effect of multiple age-classes of summer flounder (age-classes $\geq 0$ ) on winter flounder mortality may be equivalent or exceed the abovementioned predatory threats. First, in this study, winter flounder mortality calculations were based exclusively on age-0 summer flounder predation. As previously described, however, multiple ageclasses of summer flounder prey on post-settlement winter flounder, with occurrences of predation by older conspecifics comparable or surpassing those observed in this study (\%F 5-41\%) (Festa 1979, Manderson et al. 2000, 2006, Sagarese et al. 2011). Second, the number of distinct prey items that age-0 summer flounder ingest per foraging event is constrained by their stomach volume. The mean number of winter flounder occurring in age-0 summer flounder stomachs in this study, for example, was 1.2 (maximum = 2). Comparatively, previous investigations in the Navesink River/Sandy Hook Bay reported that age$1+$ summer flounder consumed, on average, 2.7 winter flounder per feeding episode, with as many as 9 and 11 winter flounder recovered from individual predator stomachs (Manderson et al. 2000, 2004, 2006). Lastly, the modeling exercise executed in this study revealed that under certain circumstances, age0 summer flounder predation contributes substantially to winter flounder cumulative mortality. Taylor et al. (2016) reported a maximum age-0 summer flounder density of $1.5 \mathrm{ind} . \mathrm{m}^{-2}$ in the oligohaline waters of the Seekonk River. At this elevated density, age- 0 summer flounder are projected to consume $~ 60 \%$ of the winter flounder cohort in the immediate area. Moreover, winter flounder mortality owing to age-0 summer flounder predation is highly responsive to variations in predator-to-prey size ratios. To this end, spatiotemporally distinct physiochemical conditions that affect interspecific growth rates may alter the relative size-structure of age-0 summer flounder and winter flounder (e.g. differing growth responses to warmer water temperatures; Taylor et al. 2016), thus leading to an intensification of the predator-prey interaction. These collective results suggest that predator-induced mortality of winter flounder owing to summer flounder predation may be substantial when multiple age-classes of the predator are considered. Further, under certain conditions, age-0 summer flounder may elicit a strong effect on winter flounder recruitment, albeit at relatively small spatiotemporal scales.

Acknowledgements. We are grateful to B. Bourque and numerous undergraduate research assistants (Roger Williams University [RWU], Bristol, RI) for their efforts in field sampling. The project described was supported in part by the RI National Science Foundation Experimental Program to Stimulate Competitive Research, the RI Science \& Technology Advisory Council Research Alliance Collaborative Grant, the RWU Foundation Fund Based Research Grant, and by Award P20RR016457 from the National Center for Research Resources. The content is solely the responsibility of the authors and does not necessarily represent the official views of the National Center for Research Resources or the National Institutes of Health.

\section{LITERATURE CITED}

Able KW, Fahay MP (1998) The first year in the life of estuarine fishes in the Middle Atlantic Bight. Rutgers University Press, New Brunswick, NJ

Able KW, Fahay MP (2010) Ecology of estuarine fishes: temperate waters of the Western North Atlantic. Johns Hopkins University Press, Baltimore, MD

Able KW, Kaiser SC (1994) Synthesis of summer flounder habitat parameters. NOAA Coastal Ocean Program Decision Analysis Series No. 1. NOAA Coastal Ocean Office, Silver Spring, MD

Bailey KM (1994) Predation on juvenile flatfish and recruitment variability. Neth J Sea Res 32:175-189

Bailey KM, Batty RS (1984) Laboratory study of predation by Aurelia aurita on larvae of cod, flounder, plaice and herring: development and vulnerability to capture. Mar Biol 83:287-291

* Bailey KM, Houde ED (1989) Predation on eggs and larvae of marine fishes and the recruitment problem. Adv Mar Biol 25:1-83

Buchheister A, Latour RJ (2011) Trophic ecology of summer flounder in lower Chesapeake Bay inferred from stomach content and stable isotope analyses. Trans Am Fish Soc 140:1240-1254

* Buchheister A, Latour RJ (2015) Diets and trophic-guild structure of a diverse fish assemblage in Chesapeake Bay, U.S.A. J Fish Biol 86:967-992

* Carreon-Martinez L, Johnson TB, Ludsin SA, Heath DD 
(2011) Utilization of stomach content DNA to determine diet diversity in piscivorous fishes. J Fish Biol 78: 1170-1182

Chambers RC, Leggett WC (1987) Size and age at metamorphosis in marine fishes: an analysis of laboratory-reared winter flounder (Pseudopleuronectes americanus) with a review of variation in other species. Can J Fish Aquat Sci 44:1936-1947

Chambers RC, Trippel EA (1997) Early life history and recruitment in fish populations. Chapman and Hall, London

Claessen D, VanOss C, De Ross AM, Persson L (2002) The impact of size-dependent predation on population dynamics and individual life history. Ecology 83:1660-1675

Collier JL, Fitzgerald SP, Hice LA, Frisk MG, McElroy AE (2014) A new PCR-based method shows that blue crabs (Callinectes sapidus (Rathbun)) consume winter flounder (Pseudopleuronectes americanus (Walbaum)). PLOS ONE 9:e85101

Curran MC, Able KW (1998) The value of tethering fishes (winter flounder and tautog) as a tool for assessing predation rates. Mar Ecol Prog Ser 163:45-51

* Curran MC, Able KW (2002) Annual stability in the use of coves near inlets as settlement areas for winter flounder (Pseudopleuronectes americanus). Estuaries 25:227-234

Ellis T, Gibson RN (1997) Predation of 0-group flatfishes by 0-group cod: handling times and size selection. Mar Ecol Prog Ser 149:83-90

Festa PJ (1979) Analysis of the fish forage base in the Little Egg Harbor Estuary. Tech Rep 24M. New Jersey Department of Environmental Protection, Division of Fish, Game, and Shellfisheries, Trenton, NJ

Gayanilo FC Jr, Sparre P, Pauly D (2002) FAO-ICLARM fish stock assessment tools (FiSAT II): user's manual. International Center for Living Aquatic Resources Management and Food and Agriculture Organization of the United Nations, Rome

Gibson RN (1994) Impact of habitat quality and quantity on the recruitment of juvenile flatfishes. Neth J Sea Res 32:191-206

* Gibson RN, Robb L (1992) The relationship between body size, sediment grain size and the burying ability of juvenile plaice, Pleuronectes platessa L. J Fish Biol 40: 771-778

Hjörleifsson E, Klein-MacPhee G (1992) Estimation of live standard length of winter flounder Pleuronectes americanus larvae from formalin-preserved, ethanol-preserved and frozen specimens. Mar Ecol Prog Ser 82:13-19

Jacobs RP, O'Donnell EB (2009) A pictorial guide to freshwater fishes of Connecticut. Connecticut Department of Environmental Protection, Hartford, CT

Keefe ML, Able KW (1994) Contributions of abiotic and biotic factors to settlement in summer flounder, Paralichthys dentatus. Copeia 1994:458-465

Latour RJ, Gartland J, Bonzek CF, Johnson RA (2008) The trophic dynamics of summer flounder (Paralichthys dentatus) in Chesapeake Bay. Fish Bull 106:47-57

Leopold MF, Van Damme CJG, Van der Veer HW (1998) Diet of cormorants and the impact of cormorant predation on juvenile flatfish in the Dutch Wadden Sea. J Sea Res 40:93-107

Link JS, Bolles K, Milliken CG (2002) The feeding ecology of flatfish in the Northwest Atlantic. J Northwest Atl Fish Sci 30:1-17
Malloy KD, Targett TE (1991) Feeding, growth and survival of juvenile summer flounder Paralichthys dentatus: experimental analysis of the effects of temperature and salinity. Mar Ecol Prog Ser 72:213-223

Manderson JP, Phelan BA, Bejda AJ, Stehlik L, Stoner AW (1999) Predation by striped searobin (Prionotus evolans, Triglidae) on young-of-the-year winter flounder (Pseudopleuronectes americanus, Walbaum): examining prey size selection and prey choice using field observations and laboratory experiments. J Exp Mar Biol Ecol 242:211-231

*Manderson JP, Phelan BA, Stoner AW, Hilbert J (2000) Predator-prey relations between age-1+ summer flounder (Paralichthys dentatus, Linnaeus) and age-0 winter flounder (Pseudopleuronectes americanus, Walbaum): predator diets, prey selection, and effects of sediments and macrophytes. J Exp Mar Biol Ecol 251:17-39

KManderson JP, Pessutti J, Hilbert JG, Juanes F (2004) Shallow water predation risk for a juvenile flatfish (winter flounder; Pseudopleuronectes americanus, Walbaum) in a northwest Atlantic estuary. J Exp Mar Biol Ecol 304: $137-157$

Manderson JP, Pessutti J, Shaheen P, Juanes F (2006) Dynamics of early juvenile winter flounder predation risk on a North West Atlantic estuarine nursery ground. Mar Ecol Prog Ser 328:249-265

*Morley JW, Selden RL, Latour RJ, Frölicher TL, Seagraves RJ, Pinsky ML (2018) Projecting shifts in thermal habitat for 686 species on the North American continental shelf. PLOS ONE 13:e0196127

Nilsson PA, Brönmark C (2000) Prey vulnerability to a gapesize limited predator: behavioral and morphological impacts on northern pike piscivory. Oikos 88:539-546

Nye JA, Link JS, Hare JA, Overholtz WJ (2009) Changing spatial distribution of fish stocks in relation to climate and population size within the Northeast United States continental shelf. Mar Ecol Prog Ser 393:111-129

Olla BL, Samet CE, Studholme AL (1972) Activity and feeding behavior of the summer flounder (Paralichthys dentatus) under controlled laboratory conditions. Fish Bull 70:1127-1136

Packer DB, Griesbach SJ, Berrien PL, Zetlin CA, Johnson DL, Morse WW (1999) Essential fish habitat source document: summer flounder, Paralichthys dentatus, life history and habitat characteristics. Tech Memo NOAA/ NMFS-NE-151. National Oceanic and Atmospheric Administration, Woods Hole, MA

* Paradis AR, Pepin P, Brown JA (1996) Vulnerability of fish eggs and larvae to predation: review of the influence of the relative size of prey and predator. Can J Fish Aquat Sci 53:1226-1235

Pearcy WG (1962) Ecology of an estuarine population of winter flounder, Pseudopleuronectes americanus (Walbaum), Parts I-IV. Bull Bingham Oceanogr Coll 18:1-78

Pereira J, Goldberg R, Ziskowski JJ, Berrien PL, Morse WW, Johnson DL (1999) Essential fish habitat source document: winter flounder, Pseudopleuronectes americanus, life history and habitat characteristics. Tech Memo NOAA/NMFS-NE-138. National Oceanic and Atmospheric Administration, Woods Hole, MA

* Phelan BA, Manderson JP, Stoner AW, Bejda AJ (2001) Sizerelated shifts in the habitat associations of young-of-theyear winter flounder (Pseudopleuronectes americanus): field observations and laboratory experiment with sediments and prey. J Exp Mar Biol Ecol 257:297-315 
Powell AB, Schwartz FJ (1979) Food of Paralichthys dentatus and P. lethostigma (Pisces: Bothidae) in North Carolina estuaries. Estuaries 2:276-279

Purcell JE (1985) Predation on fish eggs and larvae by pelagic cnidarians and ctenophores. Bull Mar Sci 37:739-755

Rosel PE, Kocher TD (2002) DNA-based identification of larval cod in stomach contents of predatory fishes. J Exp Mar Biol Ecol 267:75-88

Rountree RA, Able KA (1992) Foraging habits, growth, and temporal patterns of salt-marsh creek habitat use by young-of-year summer flounder in New Jersey. Trans Am Fish Soc 121:765-776

Ryer CH, Lemke JL, Boersma KS, Levas S (2008) Adaptive coloration, behavior and predation vulnerability in three juvenile north Pacific flatfishes. J Exp Mar Biol Ecol 359:62-66

Sagarese SR, Cerrato RM, Frisk MG (2011) Diet composition and feeding habits of common fishes in Long Island Bays, New York. Northeast Nat 18:291-314

Scharf FS, Juanes F, Rountree RA (2000) Predator size-prey size relationships of marine fish predators: interspecific variation and effects of ontogeny and body size on trophic-niche breadth. Mar Ecol Prog Ser 208:229-248

Scro AK, Cribari KJ, Markey KR, Taylor DL (2014) Specificity and sensitivity of a PCR-based approach for detecting winter flounder in blue crab stomachs. 14th Flatfish Biology Conference, December 3-4, 2014. Northeast Fisheries Science Center Reference Document 14-15, Woods Hole, MA

Secor DH, Dean JM, Laban EH (1991) Manual for otolith removal and preparation for microstructural examination. Baruch Institute Tech Rep 91-1, University of South Carolina, Columbia, SC

Smith SM, Hoff JG, O'Neil SP, Weinstein MP (1984) Community and trophic organization of nekton utilizing shallow marsh habitats, York River, Virginia. Fish Bull 82: 455-467

Smith LM, Whitehouse S, Oviatt CA (2010) Impacts of climate change on Narragansett Bay. Northeast Nat 17:77-90

* Sogard SM, Able KW, Hagan SM (2001) Long-term assessment of settlement and growth of juvenile winter flounder (Pseudopleuronectes americanus) in New Jersey estuaries. J Sea Res 45:189-204

Sokal RR, Rohlf FJ (1981) Biometry: the principles and practice of statistics in biological research, $2^{\text {nd }}$ edn. WH Freeman, New York, NY

Staudinger MD, Juanes F (2010a) A size-based approach to quantifying predation on longfin inshore squid Loligo pealeii in the northwest Atlantic. Mar Ecol Prog Ser 399:225-241

Staudinger MD, Juanes F (2010b) Feeding tactics of a behaviorally plastic predator, summer flounder (Paralichthys dentatus). J Sea Res 64:68-75

Stoner AW, Ottmar ML (2003) Relationships between sizespecific sediment preferences and burial capabilities in juveniles of two Alaska flatfishes. J Exp Mar Biol Ecol 282:85-101

Editorial responsibility: Myron Peck, Hamburg, Germany
Szedlmayer ST, Able KW, Rountree RA (1992) Growth and temperature-induced mortality of young-of-the-year summer flounder (Paralichthys dentatus) in Southern New Jersey. Copeia 1992:120-128

* Taylor DL (2003) Size-dependent predation on post-settlement winter flounder Pseudopleuronectes americanus by sand shrimp Crangon septemspinosa. Mar Ecol Prog Ser 263:197-215

Taylor DL (2004) Immunological detection of winter flounder (Pseudopleuronectes americanus) eggs and juveniles in the stomach contents of crustacean predators. J Exp Mar Biol Ecol 301:55-73

Taylor DL (2005a) Predatory impact of the green crab (Carcinus maenas) on post-settlement winter flounder (Pseudopleuronectes americanus) as revealed by immunological dietary analysis. J Exp Mar Biol Ecol 324:112-126

Taylor DL (2005b) Predation on post-settlement winter flounder Pseudopleuronectes americanus by sand shrimp Crangon septemspinosa in NW Atlantic estuaries. Mar Ecol Prog Ser 289:245-262

Taylor DL, Gervasi CL (2017) Feeding habits and dietary overlap between age-0 winter flounder (Pseudopleuronectes americanus) and summer flounder (Paralichthys dentatus) in southern New England tidal rivers. Fish Bull 115:167-185

Taylor DL, McNamee J, Lake J, Gervasi CL, Palance DG (2016) Juvenile winter flounder (Pseudopleuronectes americanus) and summer flounder (Paralichthys dentatus) utilization of Southern New England nurseries: comparisons among estuarine, tidal river, and coastal lagoon shallow-water habitats. Estuaries Coasts 39: 1505-1525

* Tucker JW Jr, Chester AJ (1984) Effects of salinity, formalin concentration and buffer on quality of preservation of southern flounder (Paralichthys lethostigma) larvae. Copeia 1984:981-988

*Van der Veer HW (1986) Immigration, settlement and density-dependent mortality of larval and early postlarval 0group plaice (Pleuronectes platessa) population in the western Wadden Sea. Mar Ecol Prog Ser 29:223-236

Werner EE (1986) Species interactions in freshwater communities. In: Diamond J, Case TC (eds) Ecological communities. Harper and Row, New York, NY, p 344-358

Werner EE, Gilliam JF, Hall DJ, Mittelbach GG (1983) An experimental test of the effects of predation risk on habitat use. Ecology 64:1540-1548

Wootton RJ (1998) Ecology of teleost fishes, 2nd edn. Kluwer Academic Publishers, Dordrecht

* Yamamoto M, Tominaga O (2007) Daily rations and food availability of Japanese flounder Paralichthys olivaceus, small flounder Tarphops oligolepis and sand goby Favonigobius gymnauchen at a sandy beach in the central Seto Inland Sea, Japan. Fish Sci 73:314-323

Yencho MA, Jordaan A, Cerrato RM, Baumann H, Frisk MG (2015) Growth and mortality in coastal populations of winter flounder: implications for recovery of a depleted population. Mar Coast Fish 7:246-259

Submitted: July 23, 2018; Accepted: February 4, 2019

Proofs received from author(s): February 23, 2019 